\title{
Evaluation of the Quality for the Egyptian Red Sea Coastal Waters during 2011-2013
}

\author{
Mamdouh A. Fahmy1, Laila M. Abdel Fattah'1, Ahmed M. Abdel-Halim¹, Mohamed A. Aly-Eldeen'1, \\ Ehssan M. Abo-El-Khair', Hoda H. Ahdy'1, Ahmed Hemeilly1', Ahmed Abu El-Soud², \\ Mohamed A. Shreadah ${ }^{*}$
}

${ }^{1}$ National Institute of Oceanography and Fisheries, Alexandria, Egypt

${ }^{2}$ Environmental Affairs Agency, Ministry of Environmental Affairs, Cairo, Egypt

Email: ${ }^{*}$ niof.shreadah@gmail.com

How to cite this paper: Fahmy, M.A., Fattah, L.M.A., Abdel-Halim, A.M., Aly-Eldeen, M.A., Abo-El-Khair, E.M., Ahdy, H.H., Hemeilly, A., El-Soud, A.A. and Shreadah, M.A. (2016) Evaluation of the Quality for the Egyptian Red Sea Coastal Waters during 2011-2013. Journal of Environmental Protection, 7, 1810-1834.

http://dx.doi.org/10.4236/jep.2016.712145

Received: July 4, 2016

Accepted: November 20, 2016

Published: November 23, 2016

Copyright $\odot 2016$ by authors and Scientific Research Publishing Inc. This work is licensed under the Creative Commons Attribution International License (CC BY 4.0).

http://creativecommons.org/licenses/by/4.0/

\begin{abstract}
To assess the quality of the Egyptian Red Sea coastal waters for the sustainable use and development, due to its importance for the national income, four field campaigns were annually carried out during the period from 2011-2013 to investigate the hydrography, nutrient salts, heavy metals and petroleum hydrocarbons. Except for the area of Bir Shalatein, the results of beach litter cleared out that the shoreline of the studied area is not affected by man-made litter. No sewage could be observed. The results of the present study showed that water temperature followed seasonal changes in air temperature. Red Sea water is more saline than adjacent Arabian Sea. DO revealed high values and presence of well oxygenated waters. Minor changes in the distribution of $\mathrm{pH}, \mathrm{BOD}, \mathrm{DOM}$ and $\mathrm{COD}$, revealed that limited effects of human impacts and depend mainly on the dynamics of its water as well as on the geographical location. Low Chl-a and TSM concentrations and high transparency revealed that also the effect of human impacts is almost negligible. Significantly higher sea water temperatures, TSM, $\mathrm{pH}, \mathrm{DO}, \mathrm{BOD}, \mathrm{DOM}$, and COD were observed in summer season compared to their corresponding values in winter season. Dissolved inorganic nitrogen concentrations were quite low because there is little nutrient input from soil, agriculture and pollution on land. Based on the annual mean values, the pattern concentrations of dissolved inorganic nitrogen forms followed the order: $\mathrm{NO}_{3}>$ $\mathrm{NH}_{4}>\mathrm{NO}_{2}$. The Red Sea coastal waters are classified as oligotrophic to mesotrophic state. A remarkable increase of $\mathrm{PO}_{4}$ concentration was observed in the middle Red Sea stations due to huge amounts of effluents enriched with phosphate from the main shipping and industry of Phosphate Companies. $\mathrm{SiO}_{4}$ displayed a large variability due to the supply of $\mathrm{SiO}_{4}$, which flows in the Red Sea through the strait of Bab ElMandab, biological consumption, organic matter decomposition and the partial dissolution of quartz particle transported to the sea from the surrounding desert during
\end{abstract}


sand storms. Concentrations of ammonia, phosphorus, total nitrogen, and total phosphorus were significantly higher in summer compared to their corresponding values in winter. In general, the majority of TN and TP in winter were in the form of organic-N (91.3\%) and organic P (96.8\%). The mean DIN/DIP ratio revealed high nitrogen concentrations in comparison with that of phosphorous and the surface coastal waters of the Red Sea are principally, P-limited for phytoplankton growth with higher values in winter season compared to summer season. Concentrations of heavy metals were quite low most probably due the absence of major local impacts of any land-based sources and/or any major negative impacts of coastal tourism. Regional variations were almost negligible and except for $\mathrm{Mn}, \mathrm{Cd}$, and $\mathrm{Hg}$ insignificant seasonal variations were observed. The present study revealed concentrations for metals in the acceptable levels. Furthermore, concentrations of petroleum hydrocarbons were significantly higher in winter than in summer which is mainly attributed to the increase in the rate of evaporation for petroleum hydrocarbons in summer. In general, the maximum concentration was much lower than the harmful concentrations reported for seawater. Correlation coefficients as well as principle component analysis (PCA) were applied.

\section{Keywords}

Hydrography, Nutrient Salts, Heavy Metals, Petroleum Hydrocarbons, Coastal Water, Red Sea

\section{Introduction}

The Northern Red Sea is an important sea area, not just as a unique environment, but as one of the most diverse marine ecosystems, great scientific and ecological sensitivity, and of great beauty and tourist-value. Hence, their natural resources provide a substantial economic support for the region. Furthermore, the regional resources contribute substantially to Egypt's economy, particularly in the areas of oil production, navigation, tourism and fisheries [1]-[11].

The Red Sea is $1930 \mathrm{~km}$ length and average $280 \mathrm{~km}$ in width. It is a gulf or basin of the Indian Ocean between Africa and Asia. It is a semi-enclosed, narrow water body with no river inputs. The surface area of the Red Sea is about $437,970 \mathrm{~km}^{2}$ and its mean depth is $491 \mathrm{~m}$, but it also has extensive shallow shelves, noted for their marine life and corals. The sea is the habitat of over 1000 invertebrate species, and 200 soft and hard corals [12] [13] [14] [15]. In the north, the width is only $175 \mathrm{~km}$ but southward it increases to a maximum of $370 \mathrm{~km}$ near Jizan, then decreases to 30 to $40 \mathrm{~km}$ at $\mathrm{Bab}$ El-Mandab [5] [7] [16]-[23].

The Red Sea, due to the low population density along the coast, is a considered relatively pristine area. Contamination of the Red Sea is one of the environmental crises that accompany with the rapid economic development and has become a subject of great deal of research in recent years [6] [9] [10] [18] [24]-[31]. The major threats to 
the marine environment of the Red Sea are related to land-based activities. These include urbanization and coastal development (for example, dredge and fill operations), industries including power and desalination plants and refineries, recreation and tourism, waste water treatment facilities, power plants, coastal mining and quarrying activities, oil bunkering and habitat modification such as the filling and conversion of wetlands [6] [9] [10] [18] [19] [20] [25]-[34].

The economic repercussions on the fishing and tourist trades depend, mainly on the degree of deterioration of environmental conditions. On the other hand, the rapid tourism development may lead to a serious threat to both the marine environment and the tourism industry itself, if not planned and developed on a sound environmental basis with the effective enforcement of environmental regulations combined with strong backing by scientific research and monitoring programs to control and follow up changes in the different habitats. It has been reported that areas such as Hurghada has been developed and exploited beyond their ecological and social carrying capacities and are already showing signs of environmental degradation [2] [5] [7] [8] [17] [18] [19] [20] [22] [32] [34]. Due to the importance of the area for tourism, fisheries, oil and other industries and because the economic repercussions on the fishing and tourist trades depend, to a great extent, on the degree of deterioration of environmental conditions, a proper environmental management with respect to the establishment of tourist facilities is highly desired.

The main objective of the present paper is to assess the environmental conditions including the hydrography, nutrient salts, heavy metals and petroleum hydrocarbons of the coastal waters along the Egyptian coast of the Red Sea for the management and sustainable development of the Red Sea environments.

\section{Material and Methods}

\subsection{Study Area}

The coastal zone in the Egyptian Red Sea Side, particularly in the distance between Hurghada and Bir Salatein, along a distance of $600 \mathrm{~km}$ is interesting from several points of view. In addition to the development of urban areas, ports, oil industry and may be other installations, the major asset of coastal zone is potential for development of tourism. The development of the coastal area with hotels, resorts, villages' beaches, pools, diving centers and other tourist facilities has taken place within the coastline, but in many sites as Hurghada the development has included the littoral zone and even part of the reef flat, which has been land filled. The coastal zone in between Abu Shar (El-Guona) and Bir Shalatein has attracted many investors for establishing their touristic projects along its coast. Some of these plants have been built on the course of wadies, on areas of loose sediments drifted to the wadi mouths by flash floods and torrents from the Red Sea Mountains. The Red Sea is a natural laboratory for investigating relatively rapid changes of short duration in a restricted marine environment. It covers a wide range of conditions, from normal marine, highly productive to external hypersaline and oligotrophic [21]. 


\subsection{Sampling}

Recently, an Environmental Information and Monitoring Program (EIMP) is initiated to assess the degree of deterioration of environmental conditions for a proper environmental management. Within the framework of this programm, 12 field campaigns were carried out in 3 years (2011-2013). A total of 108 coastal water samples were seasonally collected, in duplicate, during March, May, August and October of 2011-2013. Eight coastal sampling stations were selected to represent the different locations situated under the direct effect of human activities, public resort beaches, some protected and reference sites (Figure 1). The latitude and longitude of each station is given in Table 1.

\subsection{Methods}

\subsubsection{Hydrographic Parameters}

The hydrographic parameters (water temperature, salinity, $\mathrm{pH}$, Transparency, dissolved oxygen (DO) were measured in situ at each station using CTD (YSI-6000) Transparency was measured by Secchi Disk. Dissolved oxygen was also measured using modified

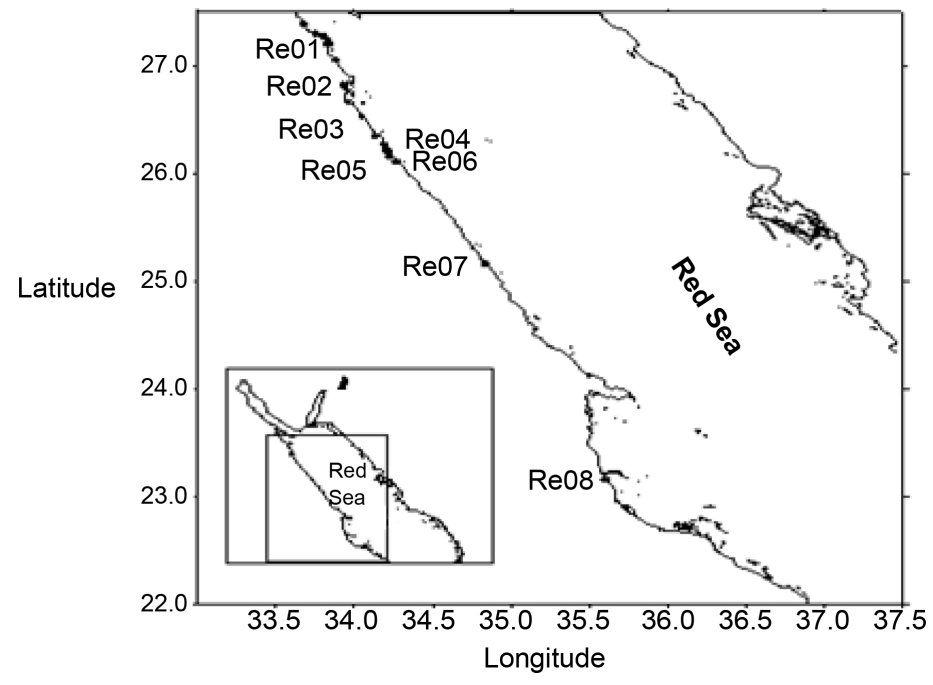

Figure 1. Locations of sampling sites along the coast of the Egyptian Red Sea.

Table 1. Locations of different sampling sites in the study area.

\begin{tabular}{lcccc}
\hline St.No & Area & Latitude & Longitude & Distance from $(\mathrm{Km})$ Hurghada $(\mathrm{km})$ \\
\hline Re 01 & Hurghada-Hotel Sheraton & $27^{\circ} 11^{\prime} 37.5^{\prime \prime}$ & $33^{\circ} 56^{\prime} 12.6^{\prime \prime}$ & 10 \\
Re 02 & Safaga north & $26^{\circ} 47^{\prime} 34.9^{\prime \prime}$ & $34^{\circ} 00^{\prime} 20.0^{\prime \prime}$ & 65 \\
Re 03 & Safaga middle & $26^{\circ} 30^{\prime} 20.0^{\prime \prime}$ & $34^{\circ} 04^{\prime} 15.0^{\prime \prime}$ & 70 \\
Re 04 & El Hamarawein & $26^{\circ} 15^{\prime} 09.0^{\prime \prime}$ & $34^{\circ} 12^{\prime} 05.0^{\prime \prime}$ & 120 \\
Re 05 & Quseir north & $26^{\circ} 12^{\prime} 15.0^{\prime \prime}$ & $34^{\circ} 13^{\prime} 15.0^{\prime \prime}$ & 140 \\
Re 06 & Quseir middle & $26^{\circ} 08^{\prime} 30.0^{\prime \prime}$ & $34^{\circ} 14^{\prime} 30.0^{\prime \prime}$ & 150 \\
$\operatorname{Re} 07$ & Marsa Alam & $25^{\circ} 04^{\prime} 06.1^{\prime \prime}$ & $34^{\circ} 45^{\prime} 00.4^{\prime \prime}$ & 275 \\
$\operatorname{Re} 08$ & Bir Shalatein & $23^{\circ} 09^{\prime} 09.9^{\prime \prime}$ & $35^{\circ} 36^{\prime} 48.3^{\prime \prime}$ & 550 \\
\hline
\end{tabular}


Winkler method [35]. Biological oxygen demand (BOD) samples were kept in incubator and fixed after 5 days and their DO contents were determined. Dissolved organic matter (DOM) was carried out using potassium permanganate according to the method described by [36], and chemical oxygen demand (COD) was determined by the dichromate closed reflux titrimetric method [35].

\subsubsection{Chlorophyll- $a$, TSM, Transparency, and Nutrient Salts}

Chlorophyll- $a$ (Chl-a) was measured in $3 \mathrm{~L}$ water samples after collection and filtration by using $0.45 \mu \mathrm{m}$ filters. Chl-a was extracted using $90 \%$ acetone and measured spectrophotometerically according to [36]. Ammonium ion concentrations were determined according to [37]. Nitrite, Nitrate, reactive phosphate and reactive silicate concentrations were determined on pre-filtered seawater samples (Whatman GF/C) following the sepectrophotometric techniques described by [37] and [38] by using HACH DR-2000 direct reading spectrophotometer. Total $\mathrm{P}$ and total $\mathrm{N}$ were estimated in unfiltered water samples following the procedure described by [39]. Total suspended matter (TSM) was collected from $3 \mathrm{~L}$ seawater samples by filtration through washed, dried and pre-weighed $0.45 \mu \mathrm{m}$ membrane filter. The filters with the retained particles were washed then air dried in the oven at $60^{\circ} \mathrm{C}$ for $24-48$ hours until constant weight. The difference between the dry weight of membrane filters before and after filtration was expressed in mg/l [37]. Transparency was measured by Secchi Disk. Transparency was measured by Secchi Disk. The concentration of dissolved inorganic nitrogen (DIN as the sum of $\mathrm{NH}_{4}-\mathrm{N}+\mathrm{NO}_{2}-\mathrm{N}+\mathrm{NO}_{3}-\mathrm{N}$ ) was calculated.

\subsubsection{Heavy Metals}

Dissolved heavy metals, i.e. $\mathrm{Fe}, \mathrm{Mn}, \mathrm{Cu}, \mathrm{Zn}, \mathrm{Cd}, \ldots$ etc. were determined after pre-concentration from seawater by using chelex-100 cation-exchange resins according to [40] and [41]. Measurements were done by using the atomic absorption spectrophotometer (AAS)/flame mode (Shimadzu AA-6800).

\subsubsection{Petroleum Hydrocarbons}

Petroleum hydrocarbons were extracted from seawater samples by using dichloromethane. Sample extracts were concentrated by rotary evaporation to $5 \mathrm{ml}$. Finally, samples were concentrated under a gentle stream of pure nitrogen to a final volume of $1 \mathrm{ml}$, then measured using UV-spectrophotometer at $410 \mathrm{~nm}$ emission after excitation at 360 $\mathrm{nm}$ and chrysene as standard [42].

\subsection{Quality Control}

Calibration curves for each variable of nutrient salts and heavy metals were constructed of a blank and four or more standards (Merck Germany). Accuracy and precision were confirmed using synthetic samples and/or reference materials of different nutrient salts and metals and measured every five samples as quality control tools.

\subsection{Statistical Analysis}

A stepwise multiple linear regression to give insight about the relationships between the 
independent variables and the dependent variables were calculated $(\mathrm{n}=106 \mathrm{p} \leq 0.05)$ to test the relationship between variables. The correlation coefficient is significant at $r \geq$ 0.195. Analysis of variance (ANOVA) was applied to test significant differences in the measured variables and correlation matrices were constructed from the resulting coefficients with the aid of STATISTICA 10 program. Principle component analysis (PCA) and factor analysis as Varimax normalization rotated were applied with SPSS program version 15.0 for Windows. The number of factors was determined by the total variance explained, i.e. communality, usually more than $85 \%$ was necessary.

\section{Results and Discussion}

\subsection{Visual Observations}

Beach litter of lumps of new and old tar, oil, feces, sewage disposal, general and harmful liters as well as seaweeds of coastal beach zones especially those used for recreational purposes including pollution index and the magnitudes of pollution for respective items are assessed by eyes according to: none, light, moderate and heavy, allocating respective scores ranging from "0" to " 3 " (Table 2). Besides affecting the fishing industry and scuba diving tourism, beach litter cause a destruction of living resources and reduces the recreational utility of coastal waters, especially the beaches through shore damage [43]-[51].

Except for the area of Bir Shalatein, the results of Table 3 of respective years and

Table 2. The total scores of seven items stand for the pollution index.

\begin{tabular}{ccccc}
\hline Item & None & Light & Moderate & Heavy \\
\hline Lumps of new and old tar & 0 & 1 & 2 & 3 \\
Oil & 0 & 1 & 2 & 3 \\
Faces & 0 & 1 & 2 & 3 \\
Seaweeds & 0 & 1 & 2 & 3 \\
General Litter & 0 & 1 & 2 & 3 \\
Harmful Litter & 0 & 1 & 2 & 3 \\
Sewage & 0 & 1 & 2 & 3 \\
\hline
\end{tabular}

Table 3. Magnitudes of pollution of respective years and annual average monitoring stations.

\begin{tabular}{cccccc}
\hline & Stations & \multicolumn{3}{c}{ Respective years } & Av. \\
\hline No. & Area & 2011 & 2012 & 2013 \\
\hline Re 01 & Hurghada-Hotel & 0.18 & 0.18 & 0.07 & 0.14 \\
Re 02 & Safaga north & 0.00 & 0.04 & 0.07 & 0.04 \\
Re 03 & Safaga middle El & 0.93 & 0.54 & 0.28 & 0.58 \\
$\operatorname{Re} 04$ & Hamarawein & 0.25 & 0.46 & 0.36 & 0.36 \\
$\operatorname{Re} 05$ & Quseir north & 0.32 & 0.46 & 0.36 & 0.38 \\
$\operatorname{Re} 06$ & Quseir middle & 0.43 & 0.46 & 0.21 & 0.37 \\
$\operatorname{Re} 07$ & Marsa Alam & 0.39 & 0.21 & 0.21 & 0.27 \\
$\operatorname{Re} 08$ & Bir Shalatein & 0.96. & 0.89 & 0.89 & 0.91 \\
\hline
\end{tabular}


annual average monitoring for the density, composition, and distributions at different stations cleared out that the shoreline of the Egyptian Red Sea can be considered relatively not affected by man-made litter. The area of Bir Shalatein (Re 08) was subjected to many factors which undoubtedly affected the rate of man-made litter accumulation including general litter, harmful litter, seaweeds, sewage, faces, ... etc. [45]-[50], yet it is not affected by oil contamination (oil and old or new tar) which is a good estimator of levels of oil contamination and an effective means of evaluating the potential threat of oil on coastal resources [45]-[51].

In general, the most abundant visible items were general litter as they represented $42.5 \%$ of the total items encountered. Seaweeds, on the other hand, represented $24.6 \%$ followed by faces and Oil which constituted $11.5 \%$ and $10.7 \%$; respectively. On contrast, harmful litter and tar balls represented $8.3 \%, 2.4 \%$, respectively. No sewage could be observed during the three respective years (2011-2013).

\subsection{Physicochemical Characteristics}

The ranges as well as average values of temperature, salinity $\mathrm{pH}, \mathrm{DO}, \mathrm{BOD}, \mathrm{DOM}$, COD of the Red Sea surface coastal waters are listed in Table 4. It has been reported that the Red Sea has a number of unique features. It is the warmest of the world's seas. The climate is equatorial $35^{\circ} \mathrm{C}-41^{\circ} \mathrm{C}$. The average water temperature is $18^{\circ} \mathrm{C}-21^{\circ} \mathrm{C}$ in

Table 4. Ranges and average values of physicochemical parameters of coastal surface waters of Red Sea during 2011-2013.

\begin{tabular}{|c|c|c|c|c|c|c|c|c|c|c|c|c|c|c|}
\hline \multirow{2}{*}{$\begin{array}{c}\text { Stations } \\
\text { Hurghada-Hotel Sheraton }\end{array}$} & \multirow{2}{*}{$\begin{array}{l}\text { Code } \\
\text { Re1 }\end{array}$} & \multirow{2}{*}{$\begin{array}{l}\text { Temp. }\left({ }^{\circ} \mathrm{C}\right) \\
23.0128 .98\end{array}$} & \multicolumn{2}{|c|}{ Salinity (S\%o) } & \multirow{2}{*}{$\begin{array}{c}\mathrm{pH} \\
8.148 .29\end{array}$} & \multicolumn{2}{|c|}{ Do (mg/l) } & Do \% & \multicolumn{2}{|c|}{$\mathrm{BOD}(\mathrm{mg} / \mathrm{l})$} & \multicolumn{2}{|c|}{ DOM (mg/l) } & \multicolumn{2}{|c|}{$\mathrm{COD}(\mathrm{mg} / \mathrm{l})$} \\
\hline & & & 39.35 & 40.21 & & 5.84 & 9.24 & $95.61 \quad 151.39$ & 0.28 & 5.42 & 0.08 & 0.88 & 2.51 & 9.40 \\
\hline & & 25.99 & \multicolumn{2}{|c|}{39.79} & 8.22 & \multicolumn{2}{|c|}{7.34} & 114.11 & \multicolumn{2}{|c|}{1.85} & \multicolumn{2}{|c|}{0.48} & \multicolumn{2}{|c|}{7.59} \\
\hline \multirow[t]{2}{*}{ Safaga North } & $\operatorname{Re} 2$ & $22.93 \quad 29.51$ & 39.34 & 40.12 & 8.148 .29 & 5.35 & 8.41 & $87.65 \quad 137.73$ & 0.28 & 4.36 & 0.16 & 0.88 & 2.51 & 9.64 \\
\hline & & 26.26 & \multicolumn{2}{|c|}{39.78} & 8.23 & \multicolumn{2}{|c|}{6.49} & 101.07 & \multicolumn{2}{|c|}{1.43} & \multicolumn{2}{|c|}{0.46} & \multicolumn{2}{|c|}{7.54} \\
\hline \multirow[t]{2}{*}{ Safaga Middle } & $\operatorname{Re} 3$ & $22.33 \quad 29.32$ & 39.46 & 40.36 & 8.108 .21 & 4.80 & 8.13 & $78.54 \quad 133.18$ & 0.42 & 3.06 & 0.08 & 1.32 & 2.51 & 11.20 \\
\hline & & 25.91 & \multicolumn{2}{|c|}{39.95} & 8.17 & \multicolumn{2}{|c|}{6.40} & 99.22 & \multicolumn{2}{|c|}{1.23} & \multicolumn{2}{|c|}{0.70} & \multicolumn{2}{|c|}{8.32} \\
\hline \multirow[t]{2}{*}{ El Hamarawein } & $\operatorname{Re} 4$ & $19.41 \quad 28.74$ & 38.40 & 40.10 & 8.138 .22 & 5.00 & 8.69 & $81.95 \quad 142.28$ & 0.56 & 1.53 & 0.16 & 1.04 & 2.97 & 10.00 \\
\hline & & 25.08 & & 40 & 8.19 & 6. & 55 & 100.82 & & & & & & 36 \\
\hline Quseir North & $\operatorname{Re} 5$ & $22.98 \quad 29.46$ & 38.95 & 41.03 & 8.108 .22 & 4.87 & 9.38 & $79.68 \quad 153.66$ & 0.28 & 1.76 & 0.08 & 2.16 & 6.17 & 11.08 \\
\hline & & 25.87 & & 72 & 8.18 & 6. & 45 & 100.19 & & & & & & 75 \\
\hline Quseir Middle & Re6 & $22.78 \quad 29.60$ & 38.20 & 40.18 & 8.128 .23 & 5.00 & 8.13 & $81.95 \quad 133.18$ & 0.28 & 1.74 & 0.08 & 3.12 & 7.49 & 12.03 \\
\hline & & 26.44 & & 45 & 8.19 & 6. & 36 & 99.32 & & & & & & 28 \\
\hline Marsa Alam & $\operatorname{Re} 7$ & $23.72 \quad 30.65$ & 39.06 & 40.19 & 8.138 .25 & 5.07 & 11.75 & $83.09 \quad 192.36$ & 0.70 & 4.45 & 0.08 & 2.16 & 6.17 & 10.12 \\
\hline & & 26.79 & & 65 & 8.21 & 6. & 69 & 104.89 & & & & & & \\
\hline Bir Shalatin & Re8 & $24.44 \quad 38.05$ & 40.59 & 44.36 & 8.038 .26 & 4.87 & 7.09 & $79.68 \quad 123.70$ & 0.76 & 1.60 & 0.32 & 3.12 & 8.21 & 12.51 \\
\hline & & 30.31 & & 62 & 8.17 & 5. & 86 & 95.31 & & & & & & \\
\hline & Min & 19.41 & & 20 & 8.03 & 4. & 80 & 78.54 & & & & & & \\
\hline & $\operatorname{Max}$ & 38.05 & & 36 & 8.29 & 11 & .75 & 192.36 & & & & & & 51 \\
\hline & Average & 26.61 & & 01 & 8.18 & 6. & 82 & 110.44 & & & & & & \\
\hline
\end{tabular}


winter and $21^{\circ} \mathrm{C}-26^{\circ} \mathrm{C}$ in summer. Surface water temperatures remain relatively constant at $21^{\circ} \mathrm{C}-25^{\circ} \mathrm{C}$ [52]. The results of the present study cleared out that water temperature followed seasonal changes in air temperature at different stations. Temperature varied between $19.41^{\circ} \mathrm{C}$ at Re 04 during winter to $38.05^{\circ} \mathrm{C}$ at $\operatorname{Re} 08$ during summer. A slight increase in water temperature was observed in southward direction (Figure 2(a)).

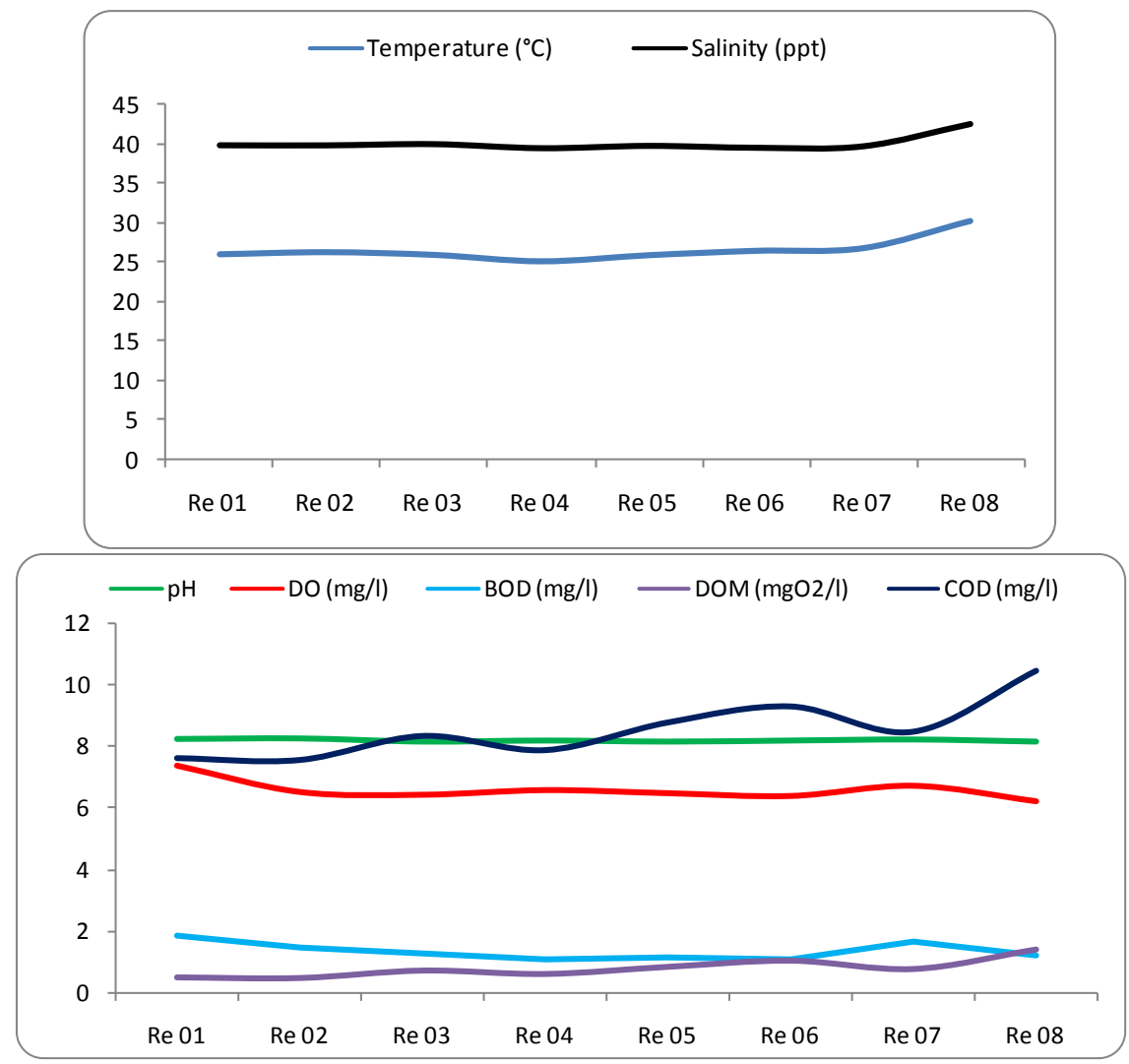

(a)

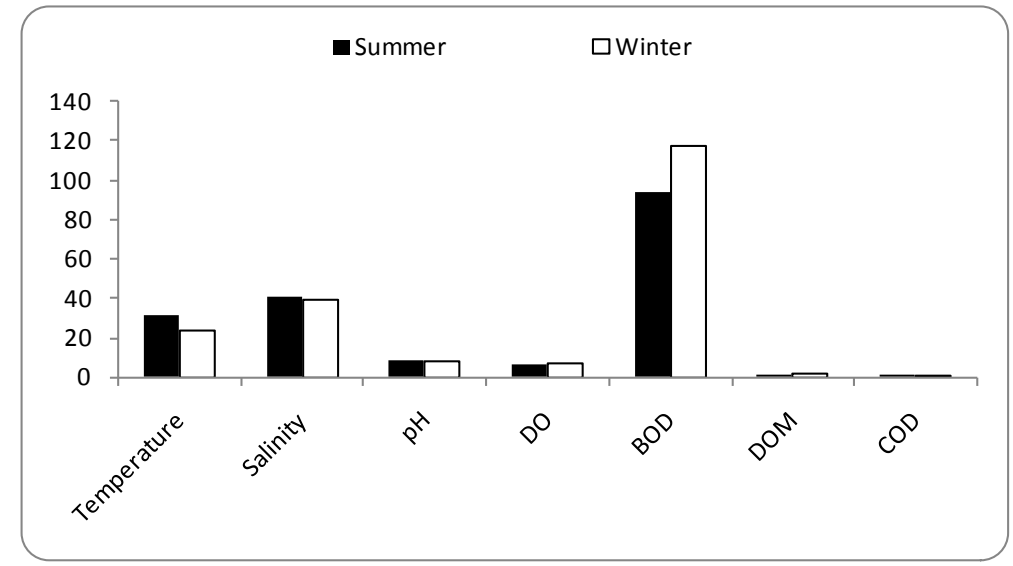

(b)

Figure 2. (a) Regional variations of different physicochemical properties of the Red Sea coastal waters; (b) Seasonal variations of different physicochemical properties of the Red Sea coastal waters. 
It is well known that the Red Sea is a concentration basin where extensive evaporation and winter cooling transform the surface waters to form one of the most saline water masses of the world Ocean [53]. Due to the high temperatures and no rivers flow into the Red Sea, the salinity in the investigated area fluctuated between $38.20 \mathrm{ppt}$ at Re 6 to $44.36 \mathrm{ppt}$ at Re 8 with a spatial average $40.01 \mathrm{ppt}$. In the Red Sea, evaporation exceeds the freshwater supply; therefore the outflow of Red Sea water is warmer and more saline than adjacent Arabian Sea [54]. $\mathrm{pH}$ values displayed no clear regional variations (Figure 2(a)). It fluctuated between 8.03 at Re 08 and 8.29 at Re 02 with an average value of 8.18. The general distribution of DO revealed high values and presence of well oxygenated waters in the investigated area (Table $4 \&$ Figure 2(a)). It ranged from 4.80 $\mathrm{mg} / \mathrm{l}(78.54 \%)$ at $\operatorname{Re} 03$ and $11.75 \mathrm{mg} / \mathrm{l}(192.36 \%)$ at Re 07 with a spatial average 6.82 $\mathrm{mg} / \mathrm{l}(110.44 \%)$. The distribution patterns of BOD, DOM and COD, on the other hand, showed no regular distribution (Figure 2(a)). They fluctuated between 0.28 - 5.42; 0.08 3.12 and $2.51-12.51 \mathrm{mg} / \mathrm{l}$, with spatial averages of $1.58 ; 0.91$ and $8.03 \mathrm{mg} / \mathrm{l}$ for BOD, DOM and COD, respectively. Minor changes in these variables revealed that the effects of human impacts on the distribution pattern of different hydrographical conditions of the Red Sea coastal waters are still limited [29] [30] [31] [55]. The low population in the region, the absence of fresh water sources and the limitation of land-based sources, i.e., sewage, agriculture and/or industrial effluents are the main reasons for such minor changes [6] [25] [30]. In fact, the environmental conditions are principally controlled by the circulation pattern of seawater in the Red Sea Regions. The hydrochemical characteristics of the Red Sea depend on the dynamics of its water as well as on the geographical location [20] [29] [31] [56] [57] [58] [59]. Seasonal variations of temperature showed significantly higher values $\left(29.36^{\circ} \mathrm{C}\right)$ in summer season compared to $23.56^{\circ} \mathrm{C}$ in winter season. On contrast, higher values of $\mathrm{pH}$ (8.23), DO (7.74 mg/l, 118.48\%), BOD $(2.18 \mathrm{mg} / \mathrm{l}), \mathrm{DOM}(1.43 \mathrm{mg} / \mathrm{l})$, and COD $(10.48 \mathrm{mg} / \mathrm{l})$ were observed in winter season compared to their corresponding values $(8.15,5.61 \mathrm{mg} / \mathrm{l}, 90.24 \%, 0.70,0.20,6.36 \mathrm{mg} / \mathrm{l}$; respectively) in winter season (Figure $2(\mathrm{~b})$ ).

\subsection{Chlorophyll- $a$, Total Suspended Matter and Secchi Disk Depth}

Ranges and regional average values of Chl-a, TSM and Secchi Disk depth are reported in Table 5. Low Chl-a and TSM concentrations and high transparency were generally encountered at most stations revealing that the effect of human impacts on the Red Sea coastal waters is still not significant [6] [20] [25] [29] [30] [31]. This can be highlighted by ranges and annual average values, at which chlorophyll-a ranged from $0.01 \mu \mathrm{g} / \mathrm{l}$ at Re 03 and $\operatorname{Re} 08$ to $3.72 \mu \mathrm{g} / \mathrm{l}$ at Re 04 with a spatial average of $0.94 \mu \mathrm{g} / \mathrm{l}$ (Figure 3(a)). Total suspended matter ranged from $1.08 \mathrm{mg} / \mathrm{l}$ at Re 02 to $38.11 \mathrm{mg} / \mathrm{l}$ at Re 6 with a spatial average of $19.74 \mathrm{mg} / \mathrm{l}$ (Figure 3(a)). Secchi Disk transparency, on the other hand, reached bottom depth at most stations confirming the absence and/or the very limited impacts of human impacts due to the low population in the region, the absence of fresh water sources and the limitation of land-based sources, i.e., sewage, agriculture and/or industrial effluents [6] [25] [30]. Seasonal variations cleared higher total suspended 
Table 5. Ranges and average values of chlorophyll-a ( $\mu \mathrm{g} / \mathrm{l})$, total suspended maters $(\mathrm{mg} / \mathrm{l})$ nutrient salts $(\mu \mathrm{g} / \mathrm{l})$ of coastal surface waters of Red Sea during 2011-2013.

\begin{tabular}{|c|c|c|c|c|c|c|c|c|c|c|c|}
\hline Station Name & Code & chll- $a$ & \multicolumn{2}{|c|}{ TSM } & $\mathrm{NH}_{4}$ & $\mathrm{NO}_{2}$ & $\mathrm{NO}_{3}$ & $\mathrm{TN}$ & $\mathrm{PO} 4$ & $\mathrm{TP}$ & $\mathrm{SiO}_{4}$ \\
\hline \multirow[t]{2}{*}{ Hurghada-Hotel Sheraton } & Re1 & $0.02 \quad 1.46$ & 1.50 & 27.40 & 4.1225 .70 & $0.78 \quad 8.50$ & 4.1238 .31 & $20.16 \quad 2244.48$ & 0.4615 .07 & $5.41 \quad 67.92$ & $31.23 \quad 81.47$ \\
\hline & & 0.50 & 16. & 64 & 9.70 & 4.28 & 14.08 & 880.36 & 2.91 & 26.44 & 54.08 \\
\hline Safaga North & $\operatorname{Re} 2$ & $0.02 \quad 0.98$ & 1.08 & 32.09 & 3.8630 .16 & $0.36 \quad 6.00$ & 3.7331 .06 & $114.24 \quad 2878.40$ & $0.00 \quad 6.03$ & 5.261748 .95 & $27.26 \quad 67.24$ \\
\hline \multirow[t]{2}{*}{ Safaga Middle } & $\operatorname{Re} 3$ & $0.01 \quad 1.02$ & 1.18 & 32.22 & 4.5236 .71 & 0.367 .00 & 4.5293 .44 & $80.64 \quad 2443.84$ & 0.6011 .30 & $5.18 \quad 114.59$ & $37.14 \quad 284.21$ \\
\hline & & 0.37 & 16. & .73 & 12.27 & 4.05 & 28.04 & 1006.56 & 3.09 & 39.33 & 106.34 \\
\hline \multirow[t]{2}{*}{ El Hamarawein } & $\operatorname{Re} 4$ & 0.103 .72 & 12.29 & 31.10 & 3.4627 .62 & 1.428 .00 & 2.4923 .96 & $87.36 \quad 2495.36$ & 0.6013 .56 & $3.53 \quad 197.90$ & 18.01161 .36 \\
\hline & & 0.66 & 20. & .92 & 10.41 & 4.47 & 11.95 & 934.77 & 3.65 & 59.63 & 68.76 \\
\hline Quseir Middle & & 0.55 & 23. & .90 & 13.08 & 4.50 & 22.82 & 960.40 & 4.21 & 33.04 & 57.62 \\
\hline \multirow[t]{2}{*}{ Marsa Alam } & $\operatorname{Re} 7$ & 0.052 .32 & 10.96 & 31.42 & 5.6756 .47 & 1.358 .50 & 6.7924 .52 & $105.28 \quad 2013.76$ & 0.0019 .59 & $5.54 \quad 1782.55$ & $28.14 \quad 128.93$ \\
\hline & & 0.80 & 21. & .35 & 14.87 & 4.77 & 13.13 & 843.48 & 4.42 & 224.62 & 66.79 \\
\hline \multirow[t]{5}{*}{ Bir Shalatin } & $\operatorname{Re} 8$ & $0.01 \quad 2.70$ & 9.82 & 30.23 & 9.0446 .47 & $1.58 \quad 8.01$ & 5.3428 .07 & $201.60 \quad 2197.44$ & 0.4622 .60 & $6.10 \quad 44.40$ & 25.89105 .20 \\
\hline & & 0.58 & 21. & .84 & 19.20 & 4.39 & 14.72 & 971.54 & 4.22 & 25.74 & 58.61 \\
\hline & Min & 0.01 & 1. & 08 & 3.24 & 0.36 & 2.49 & 20.16 & 0.00 & 3.53 & 18.01 \\
\hline & Max & 3.72 & 38. & .11 & 56.47 & 10.00 & 97.67 & 2878.40 & 22.60 & 1782.55 & 284.21 \\
\hline & Average & 0.94 & 19. & .74 & 18.85 & 4.48 & 27.01 & 1151.48 & 6.60 & 254.70 & 80.33 \\
\hline
\end{tabular}

matter $(24.80 \mathrm{mg} / \mathrm{l})$ in summer than in winter $(15.71 \mathrm{mg} / \mathrm{l})$. On contrast, higher values of chlorophyll-a $(0.51 \mu \mathrm{g} \cdot \mathrm{g} / \mathrm{l})$ were observed in winter season compared to their corresponding values $(0.39 \mu \mathrm{g} \cdot \mathrm{g} / \mathrm{l})$ in winter season showing a different seasonal pattern compared to dissolved oxygen (Figure 3(b)).

\subsection{Nutrient Salts}

Lack of riverine input and negligible precipitation mean that the nutrient-depleted ecosystem of the Red Sea relies principally on the horizontal intrusion of nutrient-rich waters from the Indian Ocean through Bab El Mandab, $\left(12.5 \times 10^{3} \mathrm{~K}^{3} \cdot \mathrm{Y}^{-1}\right)$, whereas in the northern end of the basin, nutrient enrichment is related to deep vertical mixing, i.e. winter convection and presence of a permanent cyclonic feature [56] [57] [60] [61]. Ranges as well as regional average values of different nutrients are listed in Table 5. The results indicated that dissolved inorganic nitrogen concentrations were quite low. There is strong evidence that the production potential of the Red Sea is low. Over most of the basin, thermoclines and haloclines prevent the cycling of nutrients from deeper water to the euphotic zone. There is little nutrient input to the pelagic system from land surface runoff to compensate for the steady loss by sinking of nutrients out of the 


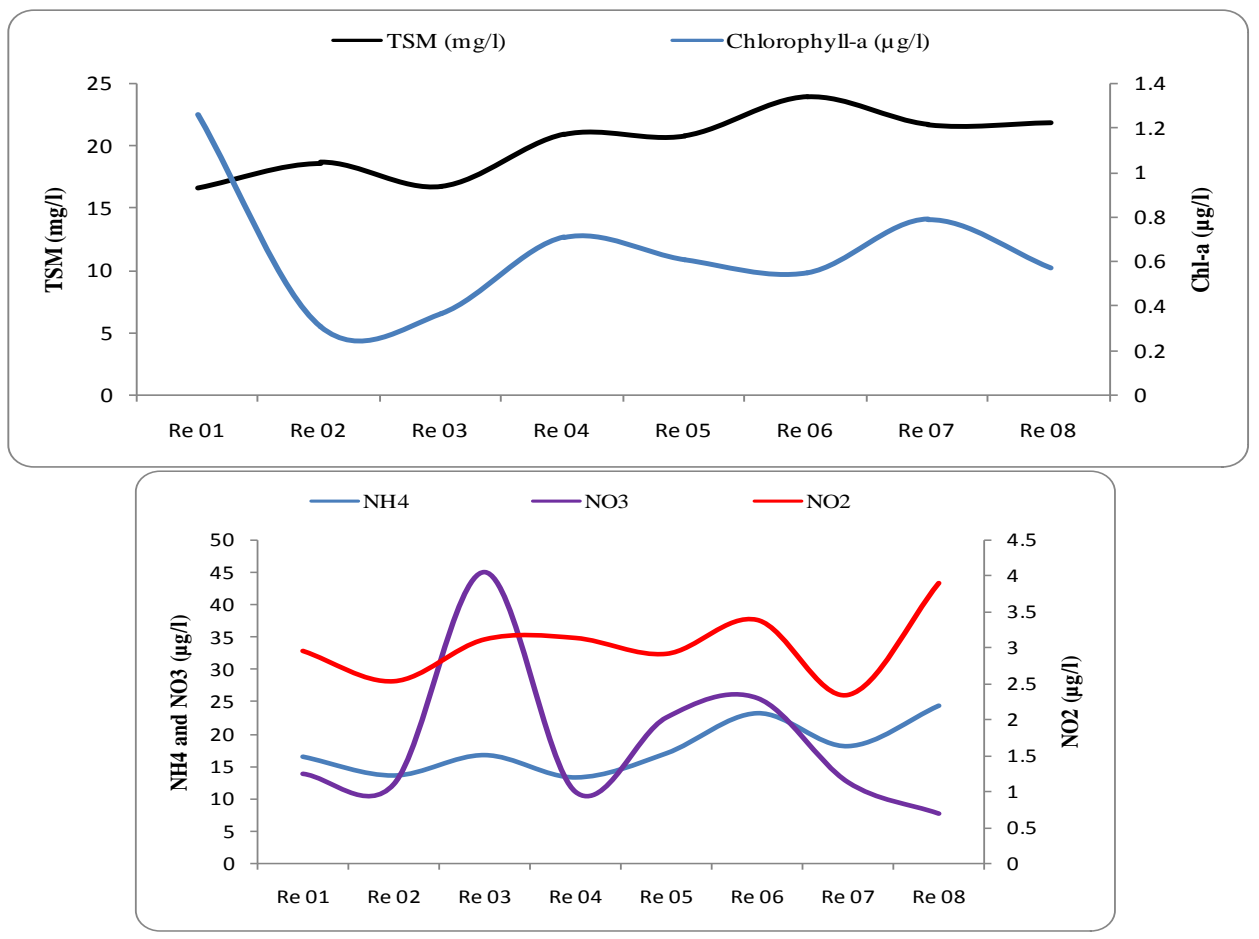

(a)

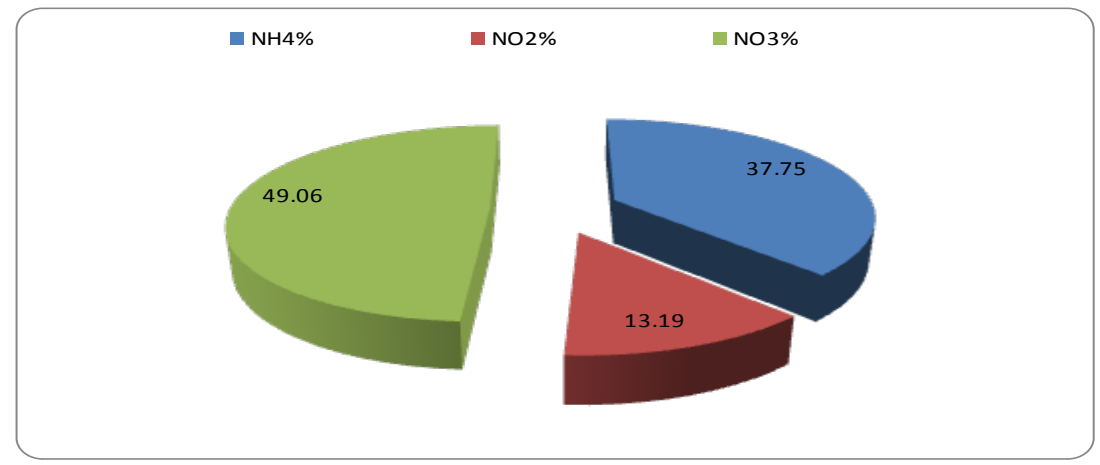

(b)

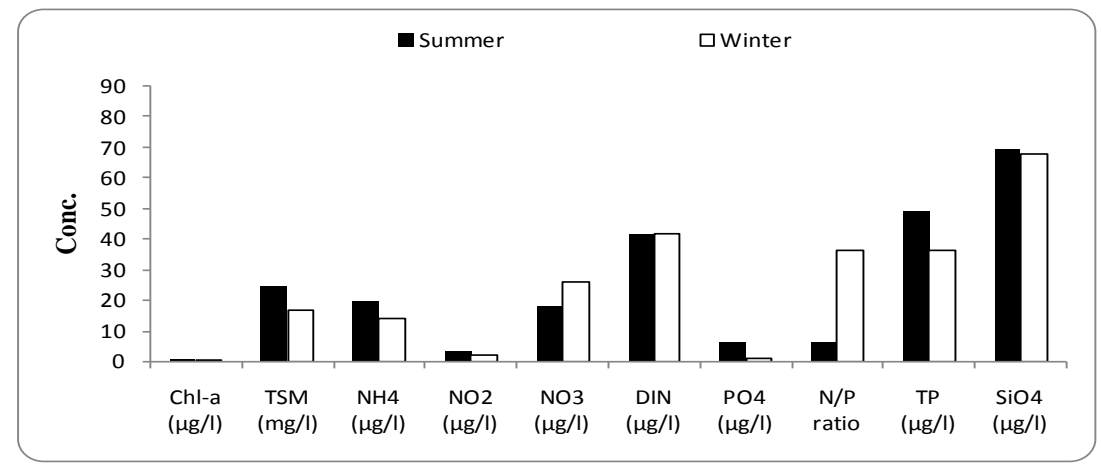

(c)

Figure 3. (a) Regional variations of Chlorophyll-a, TSM, and Nutrient Salts of the Red Sea coastal waters; (b) Nitrogen forms \% of dissolved inorganic nitrogen (DIN) based on the mean annual values of the Red Sea coastal waters; (c) Seasonal Variations of Chlorophyll-a, TSM, and nutrient salts of the Red Sea coastal waters. 
productive zone. On this basis, productivity can be expected to be low over most of the central Red Sea. Production increases somewhat to the north and south where mixing processes are known to occur [62]. The Red Sea surface waters are exceptionally clear and low in nutrients because the hot, arid climate means that population density is low and there is little nutrient input from soil, agriculture and pollution on land. It also creates a permanent surface layer of warm, nutrient-poor water, which does not mix with nutrient-rich deeper water in a process called stratification [30] [31] [57] [58] [59] [63]. They ranged from $3.24-56.47 \mu \mathrm{g} / \mathrm{l} \mathrm{NH}_{4}-\mathrm{N}$ at Re 05 and Re 07 , respectively for ammonium; $0.36 \mu \mathrm{g} / \mathrm{l} / \mathrm{l} \mathrm{NO} \mathrm{NO}_{2}-\mathrm{N}$ at $\mathrm{Re} 02$ and $\mathrm{Re} 03$ to $10.0 \mu \mathrm{g} / \mathrm{l} / \mathrm{l} \mathrm{NO} \mathrm{NO}_{2}-\mathrm{N}$ at Re 05 for nitrite; from $2.49 \mu \mathrm{g} / \mathrm{l} / 1 \mathrm{NO}_{3}-\mathrm{N}$ at $\mathrm{Re} 4$ to $97.67 \mu \mathrm{g} / 1 \mathrm{NO}_{3}-\mathrm{N}$ at $\mathrm{Re} 6$ for nitrate and from 20.16 to $2878.40 \mu \mathrm{g} / \mathrm{l} \mathrm{N}$ at Re 1 and Re 2, respectively for total nitrogen (Table 5 \& Figure 3(a)). In general, dissolved inorganic nitrogen constituted of the TN in the investigated area revealing that the majority of TN content were in the form of organic-N which constituted more than $80 \%$ of TN. Based on the mean annual values, the concentrations of dissolved inorganic nitrogen forms followed the following order: $\mathrm{NO}_{3}$ $\mathrm{NH}_{4}>\mathrm{NO}_{2}$ (Table 6, Figure 3(b)). [64] and [65] reported that seawater with concentrations of $7.0 \mu \mathrm{g} / \mathrm{l}$ for each $\mathrm{NH}_{4}$ and $\mathrm{NO}_{3}$ is classified as oligotrophic. Whereas, in eutrophic waters the concentration of these nutrients are usually in order of $28.0 \mu \mathrm{g} / \mathrm{l}$ for $\mathrm{NH}_{4}$ and $56.0 \mu \mathrm{g} / \mathrm{l}$ for $\mathrm{NO}_{3}$. According to their classification, the Red Sea coastal waters are classified as oligotrophic to mesotrophic state. On the meantime, $\mathrm{PO}_{4}$, ranged from $\mathrm{ND}$ to $22.6 \mu \mathrm{g} / \mathrm{l} \mathrm{PO}_{4}-\mathrm{P}$ at $\mathrm{Re} 02$ and Re 08 , respectively with an average value of 6.60 $\mu \mathrm{g} / \mathrm{l}$. TP ranged from 3.53 to $1782.55 \mu \mathrm{g} / \mathrm{l} \mathrm{P}$ at Re 04 and Re 07 , respectively with an average value of $254.70 \mu \mathrm{g} / \mathrm{l}$. A remarkable increase of $\mathrm{PO}_{4}$ concentration was observed in the middle Red Sea stations compared to the southern and northern stations (Figure $3(\mathrm{a})$ ). The quite high phosphorus concentrations were attributed to allochthonous huge amounts of effluents enriched with phosphate from the main shipping and industry of Phosphate Company and El Hamrawein main phosphate shipping Harbour. In the other stations $\mathrm{PO}_{4}$ concentrations were very low. Low phosphate contents could be

Table 6. Nitrogen forms percentages of dissolved inorganic nitrogen (DIN) in the Red Sea coastal waters during 2011-2013.

\begin{tabular}{ccccc}
\hline Station & code & $\mathrm{NH}_{4} \%$ & $\mathrm{NO}_{2} \%$ & $\mathrm{NO}_{3} \%$ \\
\hline Hurghada-Hotel Sheraton & $\operatorname{Re} 01$ & 34.57 & 15.25 & 50.18 \\
Safaga North & $\operatorname{Re~02}$ & 39.61 & 14.26 & 46.13 \\
Safaga Middle & $\operatorname{Re} 03$ & 27.66 & 9.13 & 63.21 \\
El Hamarawein & $\operatorname{Re~04}$ & 38.80 & 16.66 & 44.54 \\
Quseir North & $\operatorname{Re~05}$ & 33.46 & 13.09 & 53.45 \\
Quseir Middle & $\operatorname{Re} 06$ & 32.38 & 11.14 & 56.48 \\
Marsa Alam & $\operatorname{Re~07}$ & 45.38 & 14.56 & 40.06 \\
Bir Shalatin & $\operatorname{Re} 08$ & 50.12 & 11.46 & 38.42 \\
Annual mean & & 37.75 & 13.19 & 49.06 \\
\hline
\end{tabular}


mostly related to their short life cycle, sorption and deposition on iron born dust conveyed to the basin from the surrounding deserts. [66] reported the effect of composition and physicochemical characteristics of natural particles on phosphate adsorption-desorption processes under various aquatic environment. The typical concentrations for eutrophic coastal waters are above $4.65 \mu \mathrm{g} / \mathrm{l}$ and for highly eutrophic system will be beyond $9.3 \mu \mathrm{g} / \mathrm{l}$ [65]. Accordingly the obtained results are consistent with the oligotrophic characteristics of the Red Sea coastal waters [21]. The geographic and temporal distribution pattern of $\mathrm{SiO}_{4}$ displayed a large variability during the investigation period (Figure 3(a)). They fluctuated between 18.01 to $284.21 \mu \mathrm{g} / 1 \mathrm{SiO}_{4}$ at stations $\mathrm{Re} 04$ and Re 03, respectively with an average value of $80.33 \mu \mathrm{g} / \mathrm{S} \mathrm{SiO}_{4}$. A slight increase in $\mathrm{SiO}_{4}$ concentration was observed in the northern side of Red Sea coastal water. [52] pointed out the main factors controlling $\mathrm{SiO}_{4}$ distribution in the Egyptian Red Sea coastal waters are mainly: 1) the supply of $\mathrm{SiO}_{4}$, which flows in the Red Sea through the strait of Bab El Mandab, 2) biological consumption, 3) organic matter decomposition and 4) the partial dissolution of quartz particle transported to the sea from the surrounding desert during sand storms. The cycles of the key nutrient elements nitrogen $(\mathrm{N})$ and phosphorus (P) have been massively altered by anthropogenic activities [67]. In coastal marine systems, nitrogen has historically been considered to be the predominant limiting nutrient [68]. However, sequestration of $\mathrm{P}$ in calcareous sediments is thought to drive $\mathrm{P}$ limitation in the tropics [69], while constraints on planktonic $\mathrm{N}$-fixation caused by insufficient light [70] or trace metal supply [71] [72] are thought to influence the predominance of $\mathrm{N}$ or P limitation offshore. In order to understand weather the phytoplankton growth in the coastal waters of the Red Sea is, or is not, limited by $\mathrm{N}$ or $\mathrm{P}$, The $\mathrm{DIN} / \mathrm{P}$ ratio has been calculated. In the present study, DIN/P ratio amounted between (0.01:1) and (76.67:1) with a regional average value of (18.85:1) for Red Sea coastal waters. Moreover, the mean DIN/DIP ratio during the three successive years was ranging from 11.44:1 to $27.51: 1$ with an average value of $18.85: 1$. The relatively higher ratios than that reported by Redfield's ratio with value of (16:1) revealed high nitrogen concentrations in comparison with that of phosphorous and the surface coastal waters of the Red Sea are principally, P-limited for phytoplankton growth in most investigated regions. Ammonia, phosphorus, total nitrogen, and total phosphorus had similar seasonal patterns (Figure 3(c)). Seasonal variations showed average concentrations of ammonia (17.2 g/l), phosphorus $(6.42 \mathrm{~g} / \mathrm{l})$, total nitrogen $(710.0 \mathrm{~g} / \mathrm{l})$, total phosphorus $(49.74 \mathrm{~g} / \mathrm{l})$ which were significantly higher in summer compared to their corresponding values $(14.09,1.16,560,36.28 \mathrm{~g} / \mathrm{l}$; respectively) in winter. On contrast, seasonal distributions of nitrate $(25.79 \mathrm{~g} / \mathrm{l})$ exhibited significantly higher values in winter compared to their corresponding values $(18.20 \mathrm{~g} / \mathrm{l})$ in summer (Figure $3(\mathrm{~b})$ ). Nitrite and silicate exhibited more or less comparable values in winter ( $8.76 \& 68.74$; respectively) compared to their corresponding value in summer ( $8.66 \& 69.50$; respectively). In general, the majority of TN and TP in winter were in the form of organic-N (91.3\%) and organic $\mathrm{P}$ (96.8\%). These percentages were $96.2 \%$ and $87.1 \%$, respectively in summer. Moreover, the DIN/DIP ratio was ranging from 15.19 to 44.85 with an average of $45.6: 1$ showing 
higher values in winter season compared to summer season. This indicates high nitrogen concentrations in comparison with that of phosphorous in winter, yet it reflects the generally lower nutrient levels present in the coastal waters of the Red Sea due to the lack of significant riverine nutrient input or oceanic upwelling [52].

\subsection{Heavy Metals}

With the growth of industry, there has been a considerable increase in the discharge of industrial waste to the aquatic systems, which has led to the accumulation of heavy metals resulting in a major health concern worldwide, as they cannot be broken down to non-toxic forms and therefore have long-lasting effects on the ecosystem [73]-[78]. The increasing concentration of heavy metals in the marine environment due to industrial revolution has created an alarming situation for human life and aquatic biota [78] [79] [80] [81] [82]. The ranges and mean concentrations of the studied heavy metals, namely, $\mathrm{Fe}, \mathrm{Zn}, \mathrm{Mn}, \mathrm{Ni}, \mathrm{Cu}, \mathrm{Cr}, \mathrm{Cd}, \mathrm{Pb}$, and $\mathrm{Hg}$ revealed quite low concentrations (Table 7). The results of the present study (Table 7 \& Figure 4(a)) indicated that concentrations of dissolved metals in the investigated area followed the following order: $\mathrm{Fe}$ $(36.12 \mu \mathrm{g} / \mathrm{l}) \gg \mathrm{Zn}(12.91 \mu \mathrm{g} / \mathrm{l}) \gg \mathrm{Cu}(3.74 \mu \mathrm{g} / \mathrm{l})>\mathrm{Pb}(3.49 \mu \mathrm{g} / \mathrm{l})>\mathrm{Mn}(1.98 \mu \mathrm{g} / \mathrm{l})>$ $\mathrm{Ni}(1.33 \mu \mathrm{g} / \mathrm{l})>\mathrm{Cr}(1.08 \mu \mathrm{g} / \mathrm{l})>\mathrm{Cd}(0.44 \mu \mathrm{g} / \mathrm{l}) \gg \mathrm{Hg}(0.0385 \mu \mathrm{g} / \mathrm{l})$. Regional variations were almost negligible (Figure 4 (a)) which is most probably due to the lack of

Table 7. Ranges and regional average values of heavy metals $(\mu \mathrm{g} / \mathrm{l})$ in the Red Sea coastal waters during 2011-2013.

\begin{tabular}{|c|c|c|c|c|c|c|c|c|c|c|c|c|c|c|c|c|c|}
\hline \multirow{2}{*}{$\begin{array}{c}\text { Station Name } \\
\text { Hurghada-Hotel Sheraton }\end{array}$} & \multirow{2}{*}{$\begin{array}{l}\text { Code } \\
\text { Re1 }\end{array}$} & \multicolumn{2}{|c|}{$\mathrm{Fe}$} & \multicolumn{2}{|c|}{$\mathrm{Mn}$} & \multirow{2}{*}{$\begin{array}{c}\mathrm{Cu} \\
0.96\end{array}$} & \multicolumn{3}{|c|}{$\mathrm{Zn}$} & \multirow{2}{*}{\multicolumn{2}{|c|}{$\begin{array}{ll}\mathrm{Cr} & \\
0.63 & 1.43\end{array}$}} & \multirow{2}{*}{\multicolumn{2}{|c|}{$\begin{array}{ll}\mathrm{Ni} & \\
0.51 & 1.76\end{array}$}} & \multirow{2}{*}{\multicolumn{2}{|c|}{$\begin{array}{ll}\text { Cd } \\
0.25 \quad 0.97\end{array}$}} & \multirow{2}{*}{$\begin{array}{cc}\mathrm{Pb} & \\
3.39 & 6.63\end{array}$} & \multirow{2}{*}{$\begin{array}{ll}\mathrm{Hg} & \\
0.00 & 0.10\end{array}$} \\
\hline & & 12.89 & 64.62 & 0.60 & 8.98 & & 6.05 & 4.41 & 75.91 & & & & & & & & \\
\hline & & \multicolumn{2}{|c|}{33.66} & \multicolumn{2}{|c|}{3.29} & \multicolumn{2}{|c|}{3.04} & \multicolumn{2}{|c|}{22.09} & 1. & 06 & \multicolumn{2}{|c|}{1.22} & \multicolumn{2}{|c|}{0.58} & 4.35 & 0.05 \\
\hline \multirow[t]{2}{*}{ Safaga North } & $\operatorname{Re} 2$ & 25.63 & 57.16 & 0.49 & 12.73 & 1.35 & 4.87 & 7.28 & 41.22 & 0.46 & 1.46 & 0.95 & 2.06 & 0.16 & 1.18 & 2.065 .40 & $0.02 \quad 0.08$ \\
\hline & & \multicolumn{2}{|c|}{36.36} & \multicolumn{2}{|c|}{3.73} & \multicolumn{2}{|c|}{2.60} & \multicolumn{2}{|c|}{19.26} & \multicolumn{2}{|c|}{1.00} & \multicolumn{2}{|c|}{1.36} & \multicolumn{2}{|c|}{0.52} & 3.59 & 0.05 \\
\hline \multirow[t]{2}{*}{ Safaga Middle } & $\operatorname{Re} 3$ & 19.75 & 65.62 & 0.59 & 4.41 & 1.50 & 7.17 & 2.68 & 11.16 & 0.39 & 1.40 & 0.39 & 3.07 & 0.13 & 0.70 & $1.80 \quad 6.13$ & $0.04 \quad 0.07$ \\
\hline & & \multicolumn{2}{|c|}{44.02} & & 90 & & 43 & & 91 & 1. & 09 & 1. & 35 & 0 . & 35 & 3.96 & 0.05 \\
\hline El Hamarawein & Re4 & 23.50 & 56.31 & 0.52 & 2.34 & 1.61 & 14.12 & 9.40 & 15.39 & 0.73 & 1.36 & 0.98 & 1.79 & 0.24 & 0.81 & 1.326 .11 & $0.01 \quad 0.10$ \\
\hline & & 41 & 68 & & 44 & & 83 & & .85 & 1. & 09 & 1. & 33 & 0. & 49 & 3.66 & 0.06 \\
\hline Quseir North & $\operatorname{Re} 5$ & 15.04 & 40.45 & 1.22 & 4.81 & 1.21 & 8.28 & 8.15 & 14.80 & 0.76 & 1.88 & 0.68 & 3.35 & 0.23 & 0.87 & 2.623 .96 & 0.030 .06 \\
\hline & & 29 & 61 & & 02 & & 78 & & .79 & 1. & 20 & 1. & 64 & 0. & 48 & 3.38 & 0.04 \\
\hline Quseir Middle & Re6 & 21.45 & 47.10 & 0.19 & 1.55 & 1.27 & 8.43 & 5.52 & 15.79 & 0.69 & 1.54 & 0.83 & 2.27 & 0.20 & 0.61 & 2.318 .90 & $0.01 \quad 0.03$ \\
\hline & & 35 & 99 & & 98 & & 50 & & .73 & 1. & 11 & 1. & 39 & 0 . & 38 & 4.20 & 0.02 \\
\hline Marsa Alam & $\operatorname{Re} 7$ & 19.78 & 50.39 & 0.55 & 1.72 & 1.23 & 8.95 & 4.17 & 14.29 & 0.80 & 1.60 & 0.65 & 2.03 & 0.14 & 0.60 & 3.133 .96 & $0.01 \quad 0.05$ \\
\hline & & 35 & 99 & & 18 & & 51 & & 32 & 1. & 15 & 1. & 16 & 0. & 39 & 3.56 & 0.03 \\
\hline Bir Shalatin & $\operatorname{Re} 8$ & 27.62 & 40.82 & 0.26 & 2.92 & 0.64 & 6.72 & 5.94 & 24.01 & 0.72 & 1.47 & 0.56 & 1.69 & 0.15 & 0.63 & $2.44 \quad 4.24$ & 0.010 .06 \\
\hline & & 32 & 66 & & 30 & & 09 & & .34 & 0. & 91 & 1. & 19 & 0. & 37 & 3.28 & 0.02 \\
\hline & Min & 12 & 89 & & 19 & & 64 & & 68 & 0. & 39 & 0 . & 39 & 0 . & 13 & 1.32 & 0.00 \\
\hline & Max & 65 & 62 & 12 & .73 & & .12 & & .91 & 1. & 88 & 3. & 35 & 1. & 18 & 8.90 & 0.10 \\
\hline & Average & 36 & .59 & & 49 & & 34 & & .14 & 1. & 08 & 1. & 42 & 0. & 48 & 3.93 & 0.04 \\
\hline
\end{tabular}




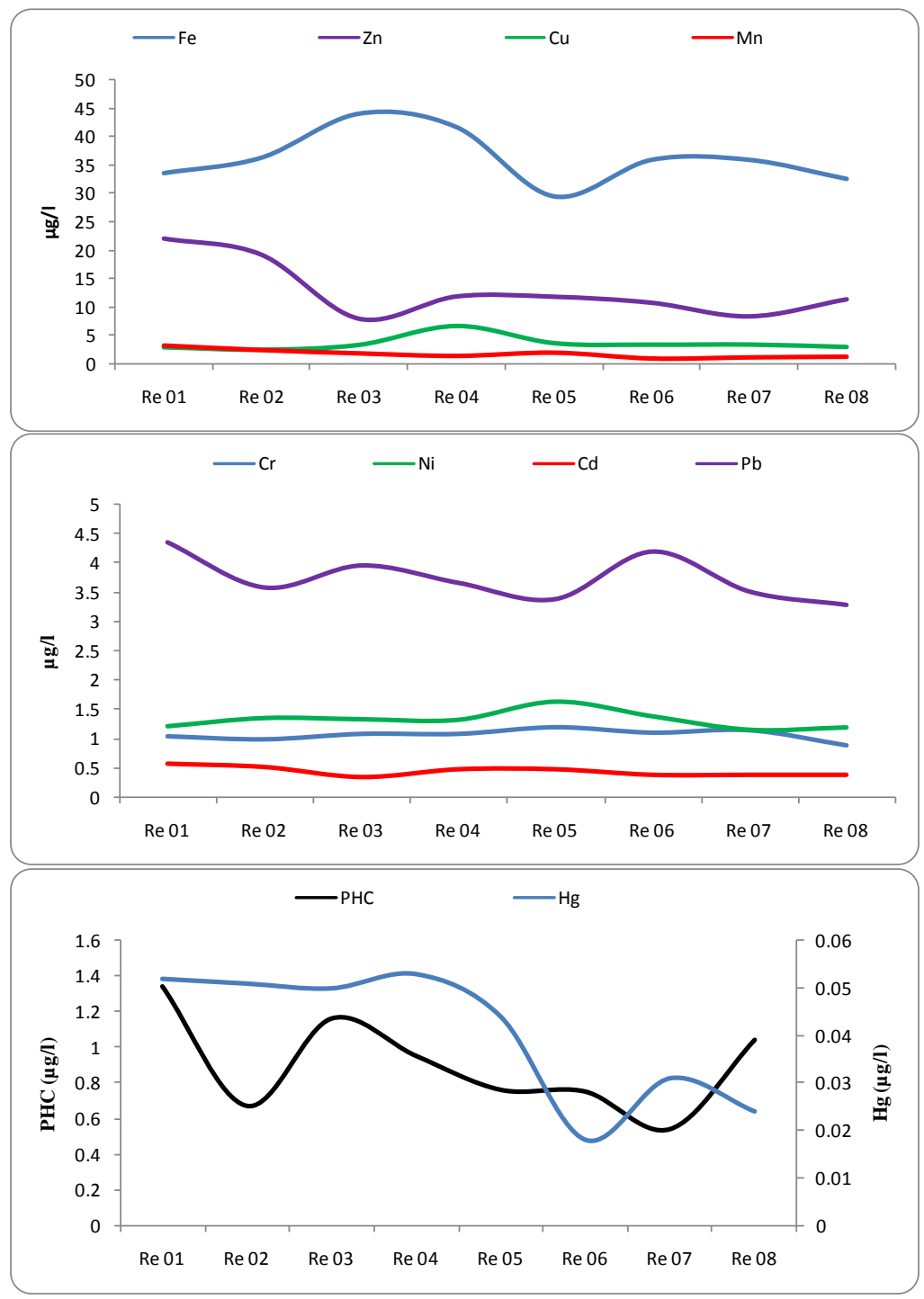

(a)

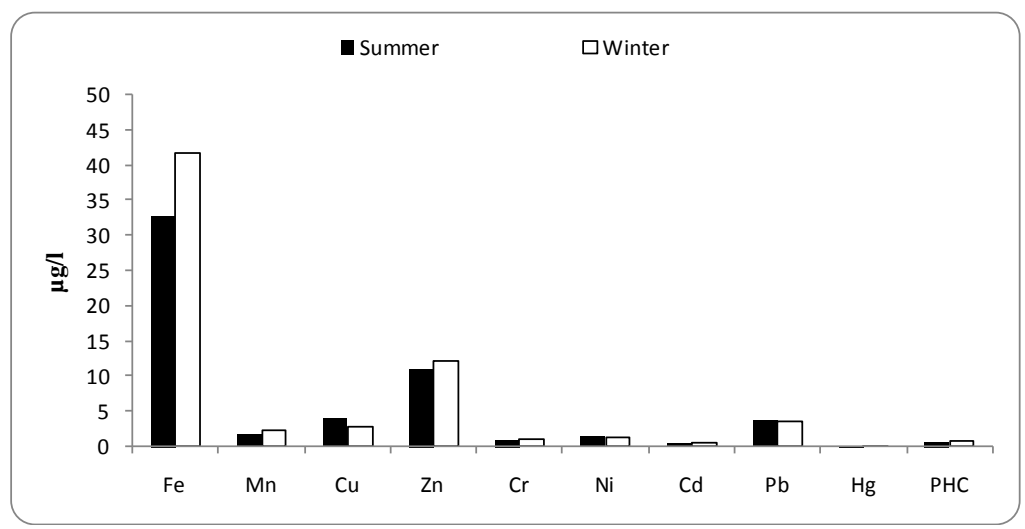

(b)

Figure 4. (a) Regional variations of heavy metals and petroleum hydrocarbons of the Red Sea coastal waters; (b) Seasonal variations of heavy metals and petroleum hydrocarbons of the Red Sea coastal waters. 
riverine input, the absence of major local impacts of any land-based sources and/or any major negative impacts of coastal tourism in the investigated area [6] [25] [29] [30] [73]. Except for $\mathrm{Mn}, \mathrm{Cd}$, and $\mathrm{Hg}$, seasonal variations, on the other hand, showed insignificant variations for most dissolved metals. Concentrations of $\mathrm{Mn}(2.36 \mathrm{~g} / \mathrm{l}), \mathrm{Cd}(0.50$ $\mathrm{g} / \mathrm{l})$, and $\mathrm{Hg}(0.043 \mathrm{~g} / \mathrm{l})$ were significantly higher in winter compared to their corresponding values $(1.64,0.35,0.032 \mathrm{~g} / \mathrm{l}$; respectively) in summer (Figure 4 (b)). The present study revealed that all water samples had acceptable metals concentrations.

\subsection{Petroleum Hydrocarbons}

Total petroleum hydrocarbons in the investigated area ranged from $0.20 \mu \mathrm{g} / \mathrm{l}$ at $\mathrm{Re} 07$ in October, 2013 and $6.86 \mu \mathrm{g} / \mathrm{l}$ at Re 01 in May, 2012, with an average of $0.91 \mu \mathrm{g} / \mathrm{l}$ (Table 7). Among all studied locations, Re 01 at Hurghada area exhibited the maximum average concentration $(1.34 \mu \mathrm{g} / \mathrm{l})$ of petroleum hydrocarbons (Figure 4(a)). Re 07 at Marsa Alam area showed the minimum average one $(054 \mu \mathrm{g} / \mathrm{l})$. The coastal waters at Hurghada area are more suffered from oil pollution compared to the other areas (Figure 4(a)) which is mainly due to accidental, deliberate or operational discharges and spills of oil from ships, especially tankers. Offshore platforms and pipelines are additional reasons for the increase of total petroleum hydrocarbons in this area [45] [46] [47] [49]. Furthermore, seasonal variations showed concentrations of petroleum hydrocarbons ranging from 0.21 to 2.5 , with an average value of $0.82 \mathrm{~g} / \mathrm{l}$ which were significantly higher in winter compared to their corresponding values (Figure 4(b)) $(0.22-1.48$, av. $0.74 \mathrm{~g} / \mathrm{l})$ in summer (Figure 4(b)). The lower concentrations of petroleum hydrocarbons in summer are mainly attributed to the increase in the rate of evaporation for petroleum hydrocarbons in summer season due to the increase in water temperature and water salinity [45] [46] [47] [48] [49]. In general, the maximum concentration was much lower than the harmful concentrations reported for seawater. On the other hand, the reported concentrations are very far below the accepted level given by EEAA of Egypt and that recorded by the International level of $500 \mu \mathrm{g} / \mathrm{l}$.

\subsection{Statistical Analysis}

\subsubsection{Correlation Analysis}

Statistically, correlation coefficient technique was applied between different measured variables to evaluate the relationships between them (Table 8). It was showed that, water temperature represents a positive significant correlation with each of salinity (0.49), COD (0.33), TSM (0.43), $\mathrm{NH}_{4}(0.49)$ and $\mathrm{PO}_{4}(0.22)$ and a negative significant correlation with each of DO (-0.51), Fe (-0.22), $\mathrm{Cd}(-0.36)$ and $\mathrm{Hg}(-0.35)$. The present study found a link among the nutrient salts, which illustrated that there was a positive significant correlation between $\mathrm{NO}_{3}$ and each of $\mathrm{NO}_{2}(0.520 .32), \mathrm{NH}_{4}(0.22)$ and $\mathrm{SiO}_{4}(0.54)$. Also, a positive significant correlation between $\mathrm{NH}_{4}$ and $\mathrm{PO}_{4}^{---}(0.36), \mathrm{NO}_{2}$ and each of $\mathrm{TN}(0.43)$ and $\mathrm{SiO}_{4}(0.41)$ were deduced. The positive correlations among the nutrients may mean that, there are all have the same source. It was observed that, there are strong relationships among the metals in the coastal water of Red Sea during the 
Table 8. Pearson correlation matrix for all investigated environmental parameters (26 parameters) during the study period ( $\mathrm{n}=96$, $\mathrm{p} \leq$ $0.05)$.

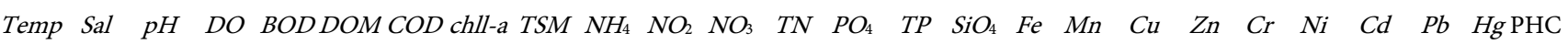

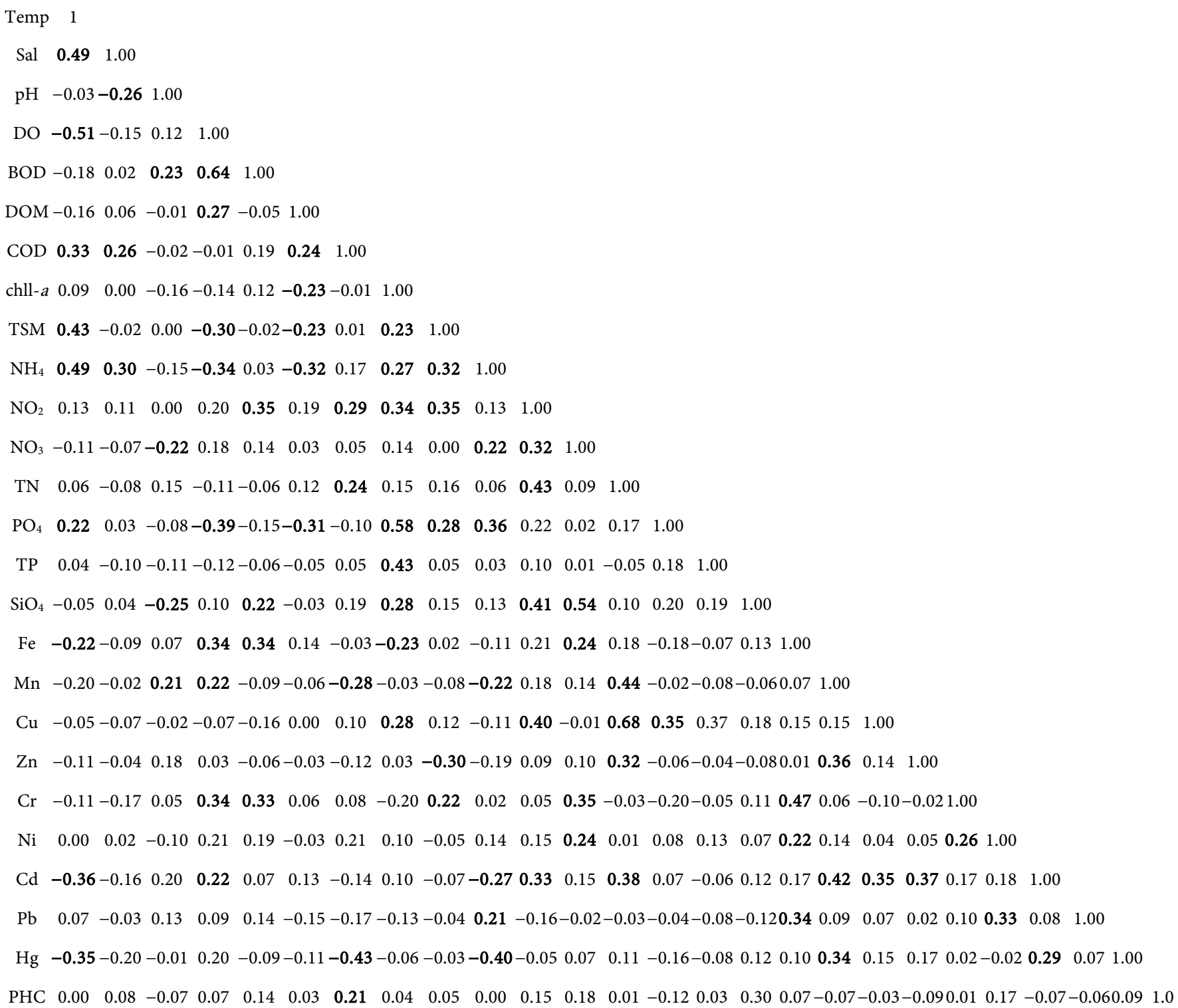

present study. There is a positive significant correlation between $\mathrm{Cd}$ and each of $\mathrm{Mn}$ (0.42) and $\mathrm{Cu}(0.35), \mathrm{Zn}(0.37)$ and $\mathrm{Hg}(0.29)$. Also there are positive significant correlations between $\mathrm{Ni}$ and each of $\mathrm{Fe}(0.22), \mathrm{Cr}(0.26)$ and $\mathrm{Pb}(0.33)$. It was found a strong positive significant correlation between $\mathrm{Fe}$ with each of $\mathrm{Cr}$ and $\mathrm{Pb}(0.47$ and 0.34 , respectively) and between $\mathrm{Mn}$ and each of $\mathrm{Hg}$ and $\mathrm{Zn}$ (0.34 and 0.36 , respectively). PHC was showed a positive significant correlation with each of $\mathrm{SiO}_{4}(0.30)$ and COD (0.21). It was observed that, there are relationships between heavy metals and nutrient salts in the coastal water of the Red Sea. A negative significant correlation between $\mathrm{NH}_{4}$ and each of $\mathrm{Mn}(-0.22), \mathrm{Cd}(-0.27)$ and $\mathrm{Hg}(-0.40)$, whereas positive significant correlations 
between $\mathrm{NO}_{2}$ with each of $\mathrm{Cu}$ and $\mathrm{Cd}\left(0.40\right.$ and 0.33 , respectively), $\mathrm{NO}_{3}$ with each of $\mathrm{Fe}$, $\mathrm{Cr}$ and $\mathrm{Ni}\left(0.24,0.35\right.$ and 0.24 , respectively), $\mathrm{PO}_{4}$ was positive correlated with $\mathrm{Cu}$ (0.35). A strong positive significant correlation between TN and each of $\mathrm{Mn}(0.44), \mathrm{Cu}$ (0.68) and $\mathrm{Zn}(0.32)$ were computed. TP was positively correlated with $\mathrm{Cu}(0.37)$. DO showed a strong positive significant correlation with each of BOD (0.64), DOM (0.27), $\mathrm{Fe}$ (0.34), Mn (0.22) $\mathrm{Cr}(0.34)$ and $\mathrm{Cd}(0.22)$, whereas, It showed a strong negative significant correlation with each of TSM $(-0.30), \mathrm{NH}_{4}(-0.34)$ and $\mathrm{PO}_{4}(-0.39)$. The relations between PHC and metals were weak.

\subsubsection{Principal Component Analysis (PCA)}

PCA is an application for assessment of water pollution. PCA is a multivariate statistical technique employed to reduce the dimensionality of dataset while attempting to preserve the relationships present in the original data. The Eigen values were computed for the standardized data using specialized statistical software package (SPSS version 16). PCA is an application for assessment of water pollution. PCA is a multivariate statistical technique employed to reduce the dimensionality of dataset while attempting to preserve the relationships present in the original data. The Eigen values were computed for the standardized data using specialized statistical software package (SPSS version 16). PCA is applied for multivariate data derived from the water analysis of 96 coastal water samples of Suez Gulf using 26 variables: water temperature, salinity, $\mathrm{pH}, \mathrm{DO}, \mathrm{BOD}$, $\mathrm{OM}, \mathrm{COD}, \mathrm{Chl}-\mathrm{a}, \mathrm{TSM}, \mathrm{NH}_{4}^{+}, \mathrm{NO}_{2}^{-}, \mathrm{NO}_{3}^{-}, \mathrm{TN}, \mathrm{PO}_{4}^{---}, \mathrm{TP}, \mathrm{SiO}_{4}, \mathrm{Fe}, \mathrm{Mn}, \mathrm{Ni}, \mathrm{Zn}$, $\mathrm{Cd}, \mathrm{Cr}, \mathrm{Pb}, \mathrm{Cu}, \mathrm{Hg}$ and $\mathrm{PHC}$. The component loadings are the linear combinations for each principal component, and the express the correlation between the original variables and the newly formed components. The component loadings are used to determine the relative importance of a variable compared to other variables in a principal component. The output data revealed that ten factors (PC1 - PC9) affected parameters distributions, association and sources, with cumulative covariance of $73.58 \%$. Varimax rotation components matrix is given in Table 9 to give an overview on the nature of loading among the parameters. PC1 explained $11.12 \%$ of the total variance, and represented positive high loading for water temperature 0.80 , salinity 0.78 , COD 0.47 and $\mathrm{NH}_{4} 0.73$ while negative high loading for DO -0.44 and $\mathrm{Hg}-0.53$. PC2 explained $10.50 \%$ of the total variance and represented positive loading for DO 0.39, TSM 0.37, $\mathrm{NO}_{2} 0.64, \mathrm{NO}_{3} 0.80, \mathrm{SiO}_{4} 0.69$ and $\mathrm{Cr} 0.37$ and negative loading for $\mathrm{pH}-0.48$. PC3 explained $8.89 \%$ of the total variance and represented high positive loading for $\mathrm{Mn} 0.72$, $\mathrm{Zn} 0.72$ and Cd 0.54 and a negative loading for TSM -0.44 . PC4 explained $8.89 \%$ of the total variance and represented high positive loading for $\mathrm{NO}_{2} 0.45, \mathrm{PO}_{4} 0.82, \mathrm{Cu} 0.84$ and Cd 0.35 . PC5 explained $8.41 \%$ of the total variance and represented high positive loading for Chll-a 0.80 , PO4 0.59 and $\mathrm{Cu} 0.35$. PC6 explained $7.55 \%$ of the total variance and represented high positive loading for $\mathrm{Fe}$ 0.61, $\mathrm{Cr} 0.46$, Ni 0.71 and $\mathrm{Pb} 0.77$. PC7 explained $7.25 \%$ of the total variance and represented positive loading for TSM 0.65 , PO4 0.44 and negative loading for DO $-0.35, \mathrm{DOM}-0.80$ and COD -0.41 . PC8 explained $6.66 \%$ of the total variance and represented positive loading for $\mathrm{pH} 0.63, \mathrm{DO}$ 0.44 and BOD 0.79 and a negative loading for $\mathrm{Hg}-0.37$. PC9 explained $4.76 \%$ of the 
Table 9. Varimax rotated component matrix for coastal water of Red Sea during 2011-2013.

\begin{tabular}{|c|c|c|c|c|c|c|c|c|c|}
\hline & PC1 & PC2 & PC3 & PC4 & PC5 & PC6 & PC7 & PC8 & PC9 \\
\hline Temp. $\left({ }^{\circ} \mathrm{C}\right)$ & 0.80 & & & & & & & & \\
\hline Salinity (S\%o) & 0.78 & & & & & & & & \\
\hline $\mathrm{pH}$ & & -0.48 & & & & & & 0.63 & \\
\hline DO & -0.44 & 0.39 & & & & & -0.35 & 0.44 & \\
\hline BOD & & & & & & & & 0.79 & \\
\hline DOM & & & & & & & -0.80 & & \\
\hline COD & 0.47 & & & & & & -0.41 & & \\
\hline Chll-a & & & & & 0.80 & & & & \\
\hline TSM & & 0.37 & -0.44 & & & & 0.56 & & \\
\hline $\mathrm{NH}_{4}^{+}$ & 0.73 & & & & & & & & \\
\hline $\mathrm{NO}_{2}$ & & 0.64 & & 0.45 & & & & & \\
\hline $\mathrm{NO}_{3}$ & & 0.80 & & & & & & & \\
\hline $\mathrm{TN}$ & & & 0.38 & 0.82 & & & & & \\
\hline $\mathrm{PO}_{4}$ & & & & & 0.59 & & 0.44 & & \\
\hline $\mathrm{TP}$ & & & & & 0.75 & & & & \\
\hline $\mathrm{SiO}_{4}$ & & 0.69 & & & & & & & \\
\hline $\mathrm{Fe}$ & & & & & & 0.61 & & & \\
\hline $\mathrm{Mn}$ & & & 0.72 & & & & & & \\
\hline $\mathrm{Cu}$ & & & & 0.84 & 0.35 & & & & \\
\hline $\mathrm{Zn}$ & & & 0.72 & & & & & & \\
\hline $\mathrm{Cr}$ & & 0.37 & & & & 0.46 & & & \\
\hline $\mathrm{Ni}$ & & & & & & 0.71 & & & \\
\hline $\mathrm{Cd}$ & & & 0.54 & 0.35 & & & & & \\
\hline $\mathrm{Pb}$ & & & & & & 0.77 & & & \\
\hline $\mathrm{Hg}$ & -0.53 & & & & & & & -0.37 & \\
\hline THC & & & & & & & & & 0.87 \\
\hline Variance \% & 11.12 & 10.50 & 8.89 & 8.44 & 8.41 & 7.55 & 7.25 & 6.66 & 4.76 \\
\hline Cumulative \% & 11.12 & 21.62 & 30.51 & 38.95 & 47.36 & 54.91 & 62.16 & 68.82 & 73.58 \\
\hline
\end{tabular}

total variance and represented high positive loading for PHC 0.87.

Statistical analysis of the results for different investigated parameters revealed that there are several commutative and correlative relations between several physicochemical parameters, nutrient salts, heavy metals and petroleum hydrocarbons.

\section{Conclusion}

It is reasonable to conclude that, the impact of the human coastal zone uses of the 
investigated locations of the Egyptian Red Sea coastal water is still limited and not noticeable on the basis of the studied parameters as well as heavy metals and total petroleum hydrocarbons, except for Bir Shalatein (station 8) in the south, which is subjected to the most intense shipping activity beside the middle region, which is located between Safaga and Quseir. This area is subjected to the most intense shipping activity and industrial discharge of phosphate in Egypt. Finally, it is safe to conclude that, the marine body of the Egyptian Red Sea coastal region is not seriously threatened in spite of recently rapid recreational human development taken place on its coast.

\section{References}

[1] Jameson, S.C., McManus, J.W. and Spalding. M.D. (1995) State of the Reefs: Regional and Global Perspectives. International Coral Reef Initiative, US Department of State, Washington DC, 32.

[2] Abd El Wahab, M. (1996) Studies on the Recent Sedimentary Environments and the Benthic Foraminifera in the Intertidal Zone of the Area between Gemsha and Marsa Alam, Red Sea, Egypt. MSc Thesis, Faculty of Science (Qena), South Valley University, New Valley, 172.

[3] FAO (1997) Review of the State of World Fishery Resources: Marine Fisheries. Western Indian Ocean. Marine Resources Service, Fishery Resources Division, Fisheries Department, FAO, Rome.

[4] Reeve, S.M., Abdel-Fattah, S.C., Riegl, R.S., Hassan, R. and Newman, A.P. (1998) Best Practices for Tourism Center Development along the Red Sea Coast. Tourism Development Authority, Cairo, 107.

[5] Mansour, A.M. (2003) Pressures and Impact of Coastal Zone of Abu Minqar and Giftun Islands, Hurghada, Red Sea, Egypt: A Management Priority. 5th International Conference on the Geology of the Middle East, Ain Shams University, Cairo, 20-21 January 2003, 417430.

[6] Okbah, M.A., Shata, M.A. and Shriadah, M.A. (2005) Geochemical Forms of Trace Metals in Mangrove Sediments-Red Sea (Egypt). Chemistry and Ecology, 21, 23-36. http://dx.doi.org/10.1080/02757540512331323953

[7] Mansour, A.M., Nawar, A.H. and Mohamed, A.M. (1997) Recent Intertidal Sediments and Negative Impact of Human Activities, Red Sea Coast, Egypt. Egyptian Journal of Geology, 41, 239-272.

[8] Mansour, A.M., Mohamed, A.W., Osman, M.R., Nasr El Dien, A. and Tahon, M.A. (2006) Sedimentlogical and Geochemical Studies on Some Island Sediments of the Red Sea, Egypt. Egytian Journal of Aquatic Research, 32, 105-130.

[9] Masoud, M.S., Said, T.O., El-Zokm, G. and Shreadah, M.A. (2010) Speciation of Fe, Mn and $\mathrm{Zn}$ in Surficial Sediments from the Egyptian Red Sea Coasts. Chemical Speciation and Biodiversity, 22, 257-269. http://dx.doi.org/10.3184/095422910X12894975123773

[10] Masoud, M.S., Said, T.O., El-Zokm, G. and Shreadah, M.A. (2012) Assessment of Heavy Metals Contamination in Surface Sediments of the Egyptian Red Sea Coasts. Australian Journal of Basic and Applied Sciences, 6, 44-58.

[11] Abdel-Halim, A.M., Abdel Nabi, M.A., Abdel Fattah, L.M., Fahmy. M.A., Abo-El-Khair, E.M., khaled, A.M., Abu El-Soud, A. and Shreadah, M.A. (2016) Environmental Studies on the Aqaba Gulf Coastal Waters during 2011-2013. Journal of Environmental Protection, 7, 1411-1437. http://dx.doi.org/10.4236/jep.2016.710121 
[12] Roberts, C.M. and Ormond, R.F.G. (1992) Butterfly Fish Social Behavior with Special Reference to the Incidence of Territoriality: A Review. Environmental Biological Fisheries, 34, 79-93. http://dx.doi.org/10.1007/BF00004786

[13] Riegl, B. and Piller, W.E. (1992) Coral Frameworks Revisited-Reefs and Coral Carpets in the Northern Red Sea. Coral Reefs, 18, 241-253. http://dx.doi.org/10.1007/s003380050188

[14] Maroof, A.K. and Kochzius, M. (2001) Community Structure and Biogeography of Shore Fishes in the Gulf of Aqaba, Red Sea. Helgoland Marine Research, 55, 252-284.

[15] Hassan, M., Kotb, M.M.A. and Al-Sofyani, A.A. (2002) Status of Coral Reefs in the Red Sea-Gulf of Aden. In: Wilkinson, C.R., Ed., Status of Coral Reefs of the World: GCRMN Report, Australian Institute of Marine Science, Townsville, Chapter 2, 45-52.

[16] Hanna, R.G.M., Saad, M.A.H. and Kandeel, M.M. (1998) Hydrographical Studies on the Red Sea Water in front of Hurghada. Marina Mesopotamica, 3, 139-156.

[17] Soliman, M.A., Ahmed, E.A. and Purser, B. (1993) Evolution of the Pliocene Sediments in the NW Part of the Red Sea Rift, Egypt. Geological Society of Egypt. Special Publication, 1, 233-251.

[18] El Saman, M.I. (2000) Hydrographic Studies of Some Lagoons near Hurghada. MSc Thesis, South Valley University, Aswan.

[19] Dar, A.M. (2002) Geological Basis to Study the Environmental Defect in the Marine Ecosystem as a Result of Tourist Activities in Hurghada Area and Surroundings, Red Sea, Egypt. PhD Thesis, Suez Canal University, Ismaïlia, 218.

[20] Fahmy, M.A. (2005) Water Quality in the Red Sea Coastal Waters (Egypt): Analysis of Spatial and Temporal Variability. Chemistry and Ecology, 19, 67-77. http://dx.doi.org/10.1080/0275754031000087074

[21] Kalmar, N.M. (2005) The Red Sea and the Gulf of Aden. Global International Waters Assessment (GIWA), Sub-Regions 48, 49, 135.

[22] Madkour, H.A., Mohamed, A.W. and Ahmed, N.A. (2008) The Impact of Anthropogenic Activities on the Physical and Chemical Characteristics of Surface Sediments in Some Coastal Lagoons along the Egyptian Red Sea Coast. Egyptian Journal of Aquatic Research, 34, 53-68.

[23] Aboul-Ela, H.M., Shreadah, M.A., Abdel-Monem, N.M., Yakout, G.A. and van Soest, R.W.M. (2012) Isolation, Cytotoxic Activity and Phylogenetic Analysis of Bacillus sp. Bacteria Associated with the Red Sea Sponge Amphimedon ochracea. Advances in Bioscience and Biotechnology, 3, 815-823. http://dx.doi.org/10.4236/abb.2012.37101

[24] UNEP (1997) Assessment of Land-Based Sources and Activities Affecting the Marine Environment in the Red Sea and Gulf of Aden. UNEP Regional Seas Reports and Studies No. 166.

[25] Shriadah, M.A., Okbah, M.A. and El-Deek, M.S. (2004) Trace Metals in the Water Columns of the Red Sea and the Gulf of Aqaba, Egypt. Water, Air and Soil Pollution, 153, 115-124. http://dx.doi.org/10.1023/B:WATE.0000019938.57041.21

[26] Shreadah, M.A., Said, T.O., Abd El Ghani, S.A. and Ahmed, A.M. (2008) Alkyllead and Alkyltin Species in Different Fishes Collected from the Suez Gulf, Egypt. Egyptian Journal of Aquatic Research, 34, 64-73.

[27] Shreadah, M.A., Said, T.O., El Zokm, G. and Masoud, M.S. (2008) Physico-Chemical Characteristics of the Surficial Sediments along the Egyptian Red Sea Coasts. Egyptian Journal of Aquatic Research, 34, 16-34.

[28] Shreadah, M.A., Masoud, M.S., Said, T.O. and El Zokm, G. (2008) Application of IR, X-Ray, TGA and DTA to Determine the Mineral Composition of the Sediments and Study of 
Reaction Kinetics along the Egyptian Red Sea Coasts. Egyptian Journal of Aquatic Research, 34, 83-95.

[29] Abo-el-Khair, E.M., Abdel Halim, A.M., Shriadah, M.A. and Fahmy, M.A. (2007) Environmental Conditions of the Suez Gulf and the Red Sea Coastal Waters, Egypt. 8 th International Conference on the Mediterranean Coastal Environment, Alexandria, 13-17 November 2007, 517-526.

[30] Abo-El khair, E.M., Abdel Halim, A.M., Fahmy, M.A. and Shreadah, M.A. (2008) Environmental Impact Assessment of Northern Red Sea Regions during 2005-2007. Egyptian Journal of Aquatic Research, 34, 20-30.

[31] Gurguess, S.M., Shreadah, M.A., Fahmy, M.A., Abo-El Kheir, E.M. and Abdel Halim, A.M. (2009) Assessment of Water Quality in the Red Sea Using in Situ Measurements and Remote Sensing Data. Egyptian Journal of Aquatic Research, 35, 1-13.

[32] Madkour, H.A. (2004) Geochemical and Environmental Studies of Recent Marine Sediments and Some Invertebrates of the Red Sea, Egypt. PhD Thesis, South Valley University, Qena, 317.

[33] Madkour, H.A., Ahmed, N.A. and Mohamed, A.W. (2006) Coastal Sediments and Their Polluting Metals of El-Hamrawein Harbour, Egyptian Red Seacoast: Clues for Monitoring Environmental Hazards. Sedimentology, 14, 131-155.

[34] Madkour, H.A. and Dar, M.A. (2007) The Anthropogenic Effluents of the Human Activities on the Red Sea Coast at Hurghada Harbour (Case Study) Egyptian Journal of Aquatic Research, 33, 43-58.

[35] APHA (1995) Standard Methods for the Examination of Water and Wastewater. 19th Edition, American Public Health Association Inc., New York.

[36] Calberg, S.R. (1972) New Baltic Manual. International Council for the Exploration of the Sea. Comparative Research Report. Series A, No. 29. Copenhagen.

[37] Intergovernmental Oceanographic Commission (1983) Chemical Methods for Use in Marine Environmental Monitoring. Manuals and Guides, Unesco, 53 p.

[38] Strickland, J.D.H. and Parsons, T.R. (1972) A Practical Hand Book of Seawater Analysis. Fisheries Research Board of Canada Bulletin 157, 2nd Edition, 310 p.

[39] Valderrama, J.C. (1981) The Simultaneous Analysis of Total Nitrogen Total Phosphorus in Natural Waters. Marine Chemistry, 10, 109-122. http://dx.doi.org/10.1016/0304-4203(81)90027-X

[40] Riley, J.P. and Taylor, D. (1968) Chelating Resins for the Concentration of Trace Elements from Sea Water and Their Analytical Use in Conjunction with Atomic Absorption Spectrophotometry. Analytica Chimica Acta, 40, 479-485. http://dx.doi.org/10.1016/S0003-2670(00)86764-1

[41] Abdullah, M.I. and Royle, L.G. (1974) A Study of the Dissolved and Particulate Trace Elements in the Bristol Channel. Journal of the Marine Biological Association, 54, 581-597. http://dx.doi.org/10.1017/S0025315400022761

[42] Parsons, T.R., Maita, Y. and Malli, G.M. (1985) Determination of Petroleum Hydrocarbons. A Manual of Chemical and Biological Method for Seawater Analysis. Pergamon Press, Oxford, 1-78.

[43] Abu-Hilal, A. and Al-Najar, T. (2004) Litter Pollution on the Jordanian Shores of the Gulf of Aqaba (Red Sea). Marine Environmental Research, 58, 39-63. http://dx.doi.org/10.1016/j.marenvres.2003.12.003

[44] Abu-Hilal, A. and Al-Najar, T. (2009) Marine Litter in Coral Reef Areas along the Jordan Gulf of Aqaba, Red Sea. Journal Environmental Management, 90, 1043-1049. 
http://dx.doi.org/10.1016/j.jenvman.2008.03.014

[45] Shriadah, M.A. (1998) Impacts of an Oil Spill on the Marine Environment of the United Arab Emirates along the Gulf of Oman. Marine Pollution Bulletin, 36, 876-879. http://dx.doi.org/10.1016/S0025-326X(98)00055-1

[46] Shriadah, M.A. (1999) Oil Contamination along Oil Tanker Routes off the United Arab Emirates (The Arabian Gulf and The Gulf of Oman). Bulletin Environmental Contamination and Toxicology, 63, 203-210. http://dx.doi.org/10.1007/s001289900967

[47] Shriadah, M.A. (1999) Petroleum Hydrocarbons along the Arabian Gulf Coast of the United Arab Emirates. Indian Journal of Marine Science, 28, 10-16.

[48] Shriadah, M.A. (2000) Contamination by Petroleum Hydrocarbons in Two Semi-Enclosed Areas along the Arabian Gulf Coast of the United Arab Emirates. Oebailla, 26, 49-62.

[49] Shriadah, M.A. (2000) Levels and Distributions of Petroleum Hydrocarbons in the Coastal Waters and Sediments of the United Arab Emirates in the Arabian Gulf and the Gulf of Oman. Water, Air and Soil Pollution, 119, 247-256. http://dx.doi.org/10.1023/A:1005192523876

[50] Shriadah, M.A. (2003) Tar Contamination on Beaches of the United Arab Emirates. Bulletin Environmental Contamination and Toxicology, 70, 680-687.

http://dx.doi.org/10.1007/s00128-003-0038-9

[51] Shriadah, M.A. (2008) Beach Litter along the Coastal Regions of the United Arab Emirates. Egyptian Journal of Aquatic Research, 34, 31-37. http://dx.doi.org/10.1016/S0964-5691(02)00112-6

[52] Gerges, M.A. (2002) The Red Sea and Gulf of Aden Action Plan-Facing the Challenges of an Ocean Gateway. Ocean \& Coastal Management, 45, 885-903. http://dx.doi.org/10.1016/S0964-5691(02)00112-6

[53] Sofianos, S.S., Johns, W. and Murray, S.P. (2002) Heat and Freshwater Budgets in the Red Sea from Direct Observations at Bab el Mandab. Deep Sea Research Part II, 49, 1323-1340. http://dx.doi.org/10.1016/S0967-0645(01)00164-3

[54] Naidu, P.D. and Nobuaki Niitsuma, N. (2003) Carbon and Oxygen Isotope Time Series Records of Planktonic and Benthic Foraminifera from the Arabian Sea: Implications on Upwelling Processes. Palaeogeography, Palaeoclimitology, Palaeoecology, 202, 85-95. http://dx.doi.org/10.1016/S0031-0182(03)00629-1

[55] Maillard, C. and Soliman, G. (1986) Hydrography of the Red Sea and Exchanges with the Indian Ocean in Summer. Oceanologia Acta, 9, 249-269.

[56] Murray, S.P. and Johns, W. (1997) Direct Observations of Seasonal Exchange through the Bab el Mandab Strait. Geophysical Research Letters, 24, 2557-2560. http://dx.doi.org/10.1029/97GL02741

[57] Johns, W.E. and Sofianos, S.S. (2012) Atmospherically Forced Exchange through the Bab el Mandeb Strait. Journal Physical Oceanography, 42, 1143-1157. http://dx.doi.org/10.1175/JPO-D-11-0157.1

[58] Bouilloux, A., Valet, J.P., Bassinat, F., Joron, J.L., Dewilde, F., Blanc-Valleron, M.M. and Moreno, E. (2013) Inflence of Seawater Exchanges across the Bab-el-Mandeb Strait on Sedimentation in the Southern Red Sea during the Last 60 ka. Paleoceanography, 28, 675-687. http://dx.doi.org/10.1002/2013PA002544

[59] Raitsos, D.E., Yi, X., Platt, T., Racault, M.F., Brewin, R.J., Pradhan, Y., Papadopoulos, V.P., Sathyendranath, S. and Hoteit, I. (2015) Monsoon Oscillations Regulate Fertility of the Red Sea. Geophysical Research Letters, 42, 855-862. http://dx.doi.org/10.1002/2014GL062882 
[60] Sofianos, S.S. and Johns, W.E. (2003) An Oceanic General Circulation Model (OGCM) Investigation of the Red Sea Circulation: 2. Three-Dimensional Circulation in the Red Sea. Journal of Geophysical Research, 108, 3066. http://dx.doi.org/10.1029/2001JC001185

[61] Triantafyllou, G., Yao, F., Petihakis, G., Tsiaras, K.P., Raitsos, D.E. and Hoteit, I. (2014) Exploring the Red Sea Seasonal Ecosystem Functioning Using a Three Dimensional Biophysical Model. Journal Geophysical Research Oceans, 119, 1791-1811.

http://dx.doi.org/10.1002/2013/C009641

[62] Zakaria, Z.A. (2003) Butter Fly Fishes of the Southern Red Sea: Ecology and Population Dynamics. Chapter I. General Introduction and Outline of the Thesis Rijksuniversiteit Groningen, Netherlands.

[63] Sofianos, S.S. and Johns, W.E. (2007) Observations of the Summer Red Sea Circulation. Journal of Geophysical Research, 112, Article ID: C06025. http://dx.doi.org/10.1029/2006jc003886

[64] Skrivanic, V.A. and Strin, J. (1982) Basic Physical Chemical and Biological Data Reports R. V. A Mohorov ICIC Adriatic Cruises 1974-76. Hydrographic Institute of Yugoslav Navy Split, 175.

[65] Franco, P. (1983) Fatorri Influent Sulla Productivita Primaria Dell Adriatico Settentrionale Proceedings of the International Conference on Problems of the Adriatic Sea, Trieste, 1983, 155 A4.

[66] Suzumura, M., Ueda, S. and Suni, E. (2000) Control of Phosphate Concentration through Adsorption and Desorption Process in Ground Water and Sea Water Mixing at Sand Beaches in Tokyo Bay. Japan Journal of Oceanographic Society, 56, 667-673. http://dx.doi.org/10.1023/A:1011125700301

[67] Elser, J.J., Bracken, M.E.S., Cleland, E.E., Gruner, D.S., Harpole, W.S., Hillebrand, H., Ngai, J.T., Seabloom, E.W., Shurin, J.B. and Smith, J.E. (2007) Global Analysis of Nitrogen and Phosphorus Limitation of Primary Producers in Freshwater, Marine and Terrestrial Ecosystems. Ecology Letters, 10, 1135-1142. http://dx.doi.org/10.1111/j.1461-0248.2007.01113.x

[68] Howarth, R.W. (1988) Nutrient Limitation of Net Primary Production in Marine Ecosystems. Annual Review Ecology Systems, 19, 89-110. http://dx.doi.org/10.1146/annurev.es.19.110188.000513

[69] Smith, S.V. (1984) Phosphorus versus Nitrogen Limitation in the Marine Environment. Limnology and Oceanography, 29, 1149-1160. http://dx.doi.org/10.4319/lo.1984.29.6.1149

[70] Karl, D.M., Bjorkman, K.M., Dore, J.E., Fujieki, L., Hebel, D.V. and Houlihan, T. (2001) Ecological Nitrogen-to-Phosphorus Stoichiometry at Station ALOHA. Deep Sea Research Part II, 48, 1529-1566. http://dx.doi.org/10.1016/S0967-0645(00)00152-1

[71] Falkowski, P.G., Barber, R.T. and Smetacek, V. (1998) Biogeochemical Controls and Feedbacks on Ocean Primary Production. Science, 281, 200-206.

http://dx.doi.org/10.1126/science.281.5374.200

[72] Wu, J., Sunda, W., Boyle, E.A. and Karl, D.M. (2000) Phosphate Depletion in the Western North Atlantic Ocean. Science, 289, 759-762. http://dx.doi.org/10.1126/science.289.5480.759

[73] Fahmy, M.A., Tayel, F.R. and Shriadah, M.A. (1997) Spatial and Seasonal Variations of Dissolved Trace Metals in Two Contaminated Basins of the Coastal Mediterranean Sea, Alexandria, Egypt. Bulletin Faculty of Science, 37, 187-198.

[74] Shriadah, M.A. (1998) Metals Pollution in Marine Sediments of the United Arab Emirates Creeks along the Arabian Gulf Shoreline. Bulletin Environmental Contamination and Toxicology, 60, 417-424. http://dx.doi.org/10.1007/s001289900642 
[75] Shriadah, M.A. (1999) Occurrence of Trace Metals in the Arabian Gulf and the Gulf of Oman sediments off the United Arab Emirates. Oebailla, 25, 43-52.

[76] Abdel-Fatah, L., Fahmy, M.A. and Shriadah, M.A. (2003) $\mathrm{Zn}, \mathrm{Cu}, \mathrm{Cd}, \mathrm{Pb}$ and $\mathrm{Hg}$ in the Egyptian Coastal Sediments along the Mediterranean Sea. Association for Modeling \& Simulation Enterprises, 64, 55-69.

[77] Shakweer, L., Shriadah, M.A., Fahmy, M.A. and Abdel Fattah, L. (2006) Distributions and Concentrations of Trace Elements along the Mediterranean Coastal Water of Egypt. Egyptian Journal of Aquatic Research, 32, 95-127.

[78] Shreadah, M.A., Fahmy, M.A. and Abdel Fattah, L. (2015) Heavy Metals in Some Fish Species and Bivalves from the Mediterranean Coast of Egypt. Journal of Environmental Protection, 6, 1-9. http://dx.doi.org/10.4236/jep.2015.61001

[79] Shriadah M.A. and Emara, H.I. (1992) Iron, Manganese, Nickel, Lead, and Cadmium in Fish and Crustacea from the Eastern Harbor and El-Mex Bay of Alexandria. Bulletin High Institute of Public Health, 22, 515-525.

[80] Shriadah, M.A. (1992) Trace Elements Concentration in Fish Samples from Alexandria Region. Bulletin High Institute of Public Health, 22, 437-444.

[81] Tayel, F.R. and Shriadah, M.A. (1996) Fe, Cu, Mn, Pb and Cd in Some Fish Species from the Western Harbor of Alexandria, Egypt. Bulletin National Institute of Oceanography \& Fisheries, 22, 85-96.

[82] Said, T.O., Farag, R.S., Younis, A.M. and Shreadah, M.A. (2006) Organotin Species in Fish and Bivalves Samples Collected from the Egyptian Mediterranean Coast of Alexandria, Egypt. Bulletin Environmental Contamination and Toxicology, 77, 451-458.

http://dx.doi.org/10.1007/s00128-006-1086-8

\section{Submit or recommend next manuscript to SCIRP and we will provide best service} for you:

Accepting pre-submission inquiries through Email, Facebook, LinkedIn, Twitter, etc.

A wide selection of journals (inclusive of 9 subjects, more than 200 journals)

Providing 24-hour high-quality service

User-friendly online submission system

Fair and swift peer-review system

Efficient typesetting and proofreading procedure

Display of the result of downloads and visits, as well as the number of cited articles

Maximum dissemination of your research work

Submit your manuscript at: http://papersubmission.scirp.org/

Or contact jep@scirp.org 